\title{
Nuclear Factor kappa B is central to Marek's Disease herpesvirus induced neoplastic transformation of CD30 expressing lymphocytes in-vivo
}

Shyamesh Kumar ${ }^{1 *+}$, Dusan Kunec ${ }^{2 \dagger}$, Joram J Buza ${ }^{3}$, Hsin-I Chiang ${ }^{4}$, Huaijun Zhou ${ }^{5}$, Sugalesini Subramaniam ${ }^{6}$, Ken Pendarvis ${ }^{7}$, Hans $\mathrm{H}$ Cheng ${ }^{8}$ and Shane C Burgess ${ }^{7,8^{*}}$

\begin{abstract}
Background: Marek's Disease (MD) is a hyperproliferative, lymphomatous, neoplastic disease of chickens caused by the oncogenic Gallid herpesvirus type 2 (GaHV-2; MDV). Like several human lymphomas the neoplastic MD lymphoma cells overexpress the CD30 antigen $\left(\mathrm{CD} 30^{\text {hi }}\right)$ and are in minority, while the non-neoplastic cells $\left(C D 30^{\circ}\right.$ ) form the majority of population. MD is a unique natural in-vivo model of human CD30 hi lymphomas with both natural CD30 hi lymphomagenesis and spontaneous regression. The exact mechanism of neoplastic transformation from CD30lo expressing phenotype to CD30 hi expressing neoplastic phenotype is unknown. Here, using microarray, proteomics and Systems Biology modeling; we compare the global gene expression of CD30 ${ }^{\text {lo }}$ and $C D 30^{\text {hi }}$ cells to identify key pathways of neoplastic transformation. We propose and test a specific mechanism of neoplastic transformation, and genetic resistance, involving the MDV oncogene Meq, host gene products of the Nuclear Factor Kappa B (NF-kB) family and CD30; we also identify a novel Meq protein interactome.

Results: Our results show that a) CD30 lo lymphocytes are pre-neoplastic precursors and not merely reactive lymphocytes; b) multiple transformation mechanisms exist and are potentially controlled by Meq; c) Meq can drive a feed-forward cycle that induces CD30 transcription, increases CD30 signaling which activates NF-kB, and, in turn, increases Meq transcription; d) Meq transcriptional repression or activation of the CD30 promoter generally correlates with polymorphisms in the CD30 promoter distinguishing MD-lymphoma resistant and susceptible chicken genotypes e) MDV oncoprotein Meq interacts with proteins involved in physiological processes central to lymphomagenesis.

Conclusions: In the context of the MD lymphoma microenvironment (and potentially in other CD30 hi lymphomas as well), our results show that the neoplastic transformation is a continuum and the non-neoplastic cells are actually pre-neoplastic precursor cells and not merely immune bystanders. We also show that NF-KB is a central player in MDV induced neoplastic transformation of CD30-expressing lymphocytes in vivo. Our results provide insights into molecular mechanisms of neoplastic transformation in MD specifically and also herpesvirus induced lymphoma in general.
\end{abstract}

Keywords: Marek's disease, Lymphomas, Meq, NF-KB, Genetic resistance, CD30, Proteomics

\footnotetext{
*Correspondence: skumar@cvm.msstate.edu; sburgess@cals.arizona.edu

${ }^{\dagger}$ Equal contributors

'Department of Pathobiology and Population Medicine, Mississippi State University, PO Box 6100, MS, Mississippi State 39762, USA

Full list of author information is available at the end of the article
} 


\section{Background}

Lymphomas are the $6^{\text {th }}$ leading cause of cancer mortality in the USA especially in patients younger than 40 years $[1,2]$. More than $11 \%$ of human lymphomas overexpress the CD30 antigen (a.k.a. Hodgkin's Disease antigen, or Tumor Necrosis Factor Receptor Superfamily Member 8 [TNFRSF8]) - this includes all Hodgkin's lymphomas (HL) and some non-Hodgkin's lymphomas (NHL); e.g. anaplastic large cell lymphoma (ALCL), primary cutaneous anaplastic large cell lymphoma (PCTL), adult T-cell leukemia/lymphoma (ATLL), peripheral T-cell lymphoma (PTCL), natural killer (NK)/T-cell lymphoma, nasal and enteropathy type $\mathrm{T}$ cell lymphoma [3-5]. Natural "spontaneous" animal models that mimic the human lymphoma microenvironment, and have a functional immune system, are invaluable tools to understand lymphoma development [6]. Marek's Disease (MD) - a CD4+ T cell lymphoma of chickens caused by the Gallid herpesvirus type 2 (GaHV-2; MDV) - is a unique natural animal model for herpesvirus induced lymphomagenesis in general and CD30 hi lymphomas specifically [7].

CD30 overexpression is an evolutionarily conserved process in neoplastic transformation in human and chicken lymphomas of different etiologies [7]. Like human CD30 hi lymphomas, MD lymphomas are a heterogeneous mix of a minority of neoplastically transformed lymphocytes $\left(\mathrm{CD} 30^{\mathrm{hi}}\right)$, surrounded by majority of non-transformed $\left(\mathrm{CD} 30^{\mathrm{lo}}\right)$ lymphocytes [8,9]. Physiologically, CD30 signaling modulates cell survival and death; however, in CD30 ${ }^{\text {hi }}$ lymphoma cells, it preferentially promotes cell survival [10,11]. CD30 overexpression (in both human and MD lymphomas) induces a $\mathrm{T}$ helper 2 (Th-2) or regulatory $\mathrm{T}$ cell (T-reg)-like cytokine microenvironment, which is antagonistic to cell mediated immunity, immune evasive $[6,12,13]$, and promotes lymphomagenesis $[8,14,15]$.

CD30 signaling activates the transcription factor $\mathrm{Nu}$ clear Factor-kappa B (NF-kB), which regulates genes associated with cell survival, proliferation, programmed cell death (PCD), stress and immunity [16]. Constitutive NF- $\mathrm{kB}$ activation, due to CD30 overexpression and ligand dependent/independent signaling, results in neoplastic transformation in human CD30 ${ }^{\text {hi }}$ lymphomas $[1,17]$. The human oncogenic viruses Epstein-Barr virus (EBV/HHV-4) and Kaposi's sarcoma-associated herpesvirus (KSHV/HHV-8) both subvert NF- $\mathrm{KB}$ activation via the CD30 signaling pathway when transforming cellsas MDV does in the chicken [18]. This suggests that the CD30 signaling pathway is fundamental, or at least highly beneficial to herpesvirus survival [18].

MD transformed lymphocytes have increased MDV oncogene "Meq" expression [19]. Meq is essential for MDV lymphomagenesis [20,21] and a positive correlation exists between Meq and CD30 expression [18].
Also, the chicken CD30 promoter has 15 known Meq binding sites, and Meq's promoter has at least one NF$\mathrm{\kappa B}$ binding site [18]. We hypothesize that a feed-forward loop exists, with Meq induced CD30 overexpression, constitutive NF- $\mathrm{kB}$ activation with resulting increased Meq transcription-favoring neoplastic transformation.

Here we show, using MD lymphocytes isolated directly ex vivo that they are either neoplastically transformed and express high levels of CD30 $\left(\mathrm{CD} 30^{\text {hi }}\right)$ or are nontransformed and express low levels of CD30 (CD30 $\left.{ }^{\text {lo }}\right)$ that: 1) neoplastic transformation is a continuum and the CD $30^{\text {lo }}$ lymphocytes within the tumor microenvironment are pre-neoplastic; 2) as the lymphocytes become more neoplastically transformed they become more immune-evasive; 3 ) the MDV oncogene Meq, has a direct role in this process and 4) NF- $\mathrm{kB}$ has a central role in this neoplastic transformation. In vitro, we show that: 1) a feed forward loop exists in which Meq activates CD30 transcription resulting in CD30 protein overexpression, which induces NF- $\mathrm{KB}$ activation which activates Meq transcription (in addition to other genes); 2) Meq and NF- $\mathrm{kB}$ transcriptional effects on the Meq promoter can be additive and that NF- $\mathrm{kB}$ isoforms have different effects; 3) Meq transcriptionally activates or represses the CD30 promoter depending on whether it is derived from a MD-susceptible or -resistant genotype; 4) the Meq interactome consists of proteins involved in physiological processes central to lymphomagenesis.

\section{Results and discussion}

Because the proteome directly affects phenotype, but the transcriptome merely influences the proteome and thus may only indirectly affect the phenotype [22-24], we based our systems biology model of neoplastictransformation in $\mathrm{MD}$ on the differences between the transformed $\mathrm{CD} 30^{\text {hi }}$, and the non-transformed CD $30^{\text {lo }}$ MD lymphocytes proteomes. We isolated CD30hi and CD 30 lo lymphocytes directly ex vivo at $>99 \%$ purity as described [12]. All comparisons and differential expressions are expressed as $\mathrm{CD} 30^{\text {hi }}$ relative to $\mathrm{CD} 30^{\mathrm{lo}}$ lymphocytes (at $\mathrm{p}<0.05$ ). Of the 11,958 proteins we identified (Additional file 1, PRIDE Accession \# 1484714852) 1,588 proteins were significantly increased, and 808 proteins had significantly decreased expression in the CD30 hi lymphocytes.

\section{Functional modeling}

To visualize the differences between the $\mathrm{CD}^{\mathrm{h}}{ }^{\mathrm{hi}}$ and $\mathrm{CD}^{\mathrm{lo}}{ }^{\mathrm{lo}}$ lymphocytes proteomes (Figure 1) in terms of well-studied cancer pathways, the differential protein expression data (Additional file 1) was manually mapped to the cancer specific pathway "Pathways in cancer" from the Kyoto Encyclopedia of Genes and Genomes (KEGG) [25] (Figure 1). This specific KEGG pathway is 


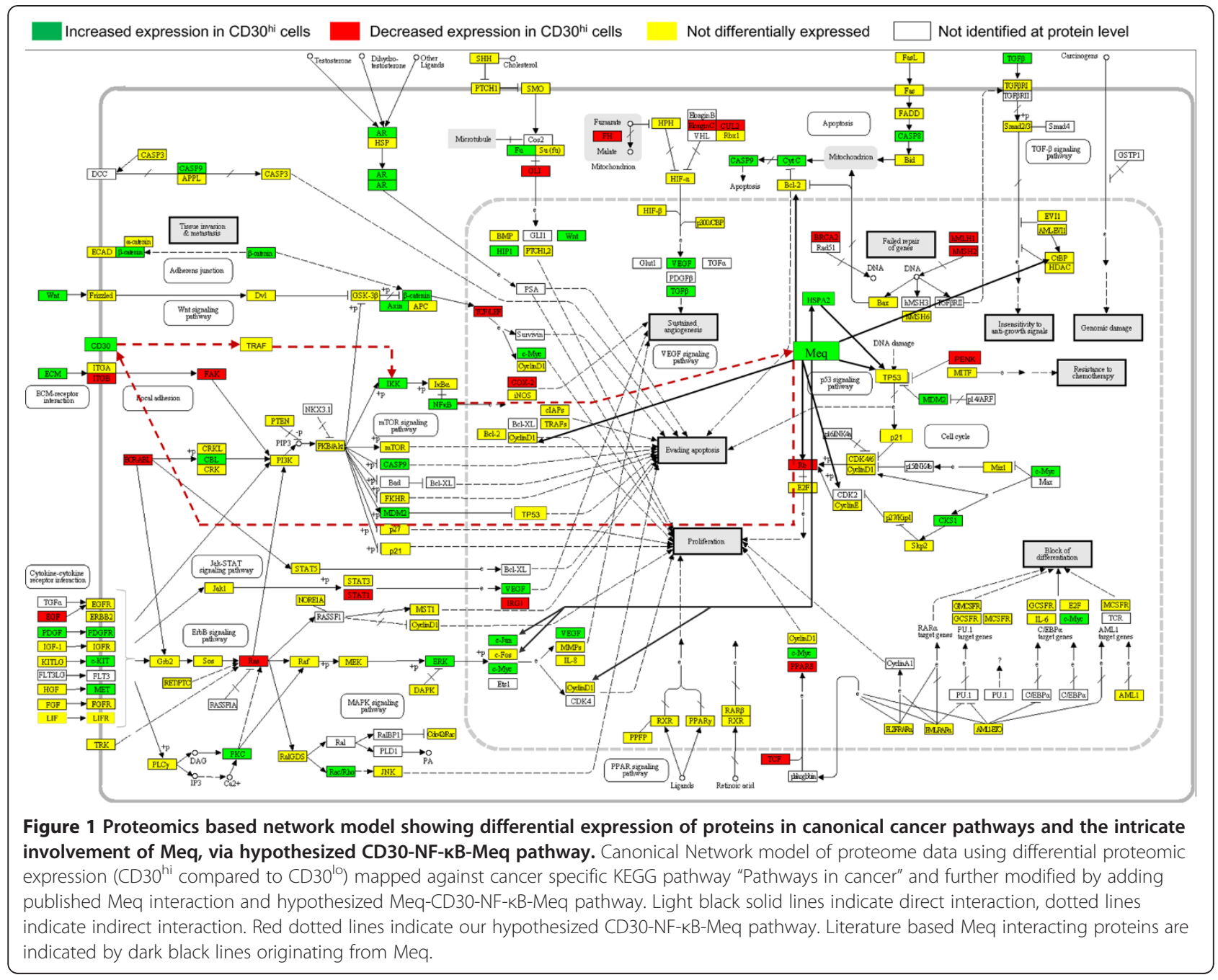

a map of several different interacting signaling pathways and so provides a comprehensive overview of the molecular signatures of $\mathrm{CD} 30^{\text {hi }}$ and $\mathrm{CD} 30^{\text {lo }}$ lymphocyte proteomes. We further modified the KEGG pathway by adding the Meq oncoprotein, previously published Meq interacting proteins, and our hypothesized Meq-CD30NF-kB feed forward loop.

A mixed pattern emerged with protein levels increasing, decreasing and not changing. However, in several of the pathways described below, key regulatory proteins were differentially expressed: NF- $\mathrm{\kappa B}$, IKK, VEGF, MDM2, CD30, HSPA2, MYC, JUN, TGF $\beta$, and Meq were increased; whereas, RB, PENK, and BRCA2 were decreased. This indicates that neoplastic transformation is being regulated by these key proteins. The MDV oncoprotein Meq interactions, and our hypothesized Meq-CD30-NF- $\mathrm{kB}$ feed-forward loop, suggest that $\mathrm{Meq}$ interacts with several key proteins involved in neoplastic transformation, immune evasion and cell survival.
Ingenuity Pathway Analysis (www.ingenuity.com, IPA)-based functional grouping of the significantly expressed pathways (data not shown) confirmed our previous findings [26] that PCD was perturbed and integrin signaling was increased in CD30 ${ }^{\text {hi }}$ cells. IPA analysis also indicated that PCD signaling, molecular mechanisms of cancer, NF- $\mathrm{kB}$ activation by viruses, $\mathrm{p} 53$ signaling, PPAR $\alpha / R X R \alpha$ activation, PTEN signaling, BRCA1 in DNA damage, VEGF signaling, Wnt/ $\beta$-catenin signaling, lymphotoxin $\beta$ receptor signaling (important in noncanonical NF- $\mathrm{\kappa B}$ activation pathway induction), TGF- $\beta$ signaling (insensitivity to antigrowth signals) and nitric oxide signaling (important in angiogenesis) were activated in both $\mathrm{CD} 30^{\mathrm{hi}}$ and $\mathrm{CD} 30^{\mathrm{lo}}$ cells. The physiological processes that the pathways affect, and the differences between the cell types, suggest that the $\mathrm{CD} 30^{\mathrm{lo}}$ lymphocytes are pre-neoplastic precursors of the $\mathrm{CD} 30^{\text {hi }}$ lymphocytes.

To this point our modeling was on a global scale. Using the same data (Additional file 1), we next tested 
eight specific functional hypotheses ( $a$ - $h$, below) pertaining to essential steps of neoplastic transformation in the transition of $\mathrm{CD} 30^{\text {lo }}$ to $\mathrm{CD} 30^{\text {hi }}$ lymphocytes:

a) Growth signals are perturbed: Growth factors control cell division and their deregulation contributes to neoplasia. IGF1 increases cell cycle and prevents PCD [27] and it is transactivated by GH1 (via STAT5 [28]). Growth hormone GH1, which interacts with MDV's SORF2 protein, is a suggested MD resistance gene [29]; however, both GH1 and SORF2 protein expression were the same in the $\mathrm{CD} 30^{\mathrm{lo}}$ and in $\mathrm{CD} 30^{\text {hi }}$ cells. Our results suggest that the growth factor effects on MD resistance identified previously (32), may either occur at an earlier stage of MD, or are unrelated to lymphomagenesis. Growth factor receptors activate pathways for growth, proliferation, differentiation, survival, migration, angiogenesis and metabolism and, in contrast to the growth factors, the growth factor receptor proteins HGFR (MET) and PDGFR were increased. HGFR, which binds FAS and inhibits PCD, is also over-expressed in human CD30 ${ }^{\text {hi }}$ lymphomas [30-34] as is PDGFR [35-37]. PDGFR over-expression can also make cells hyperresponsive to PDGF [36]. CD30 hi lymphocytes also had 4-fold more nuclear-located ERBB protein and over-expression and nuclear localization of ERBB-1 and -2 are common in tumors [38].

Growth factor receptors activate the MAPK, JAKSTAT, and, through PI3K/AKT, the MTOR signaling pathways. The MAPK pathway activates JUN, FOS and MYC, and the JAK-STAT pathway activates VEGF and both promote proliferation and angiogenesis. In the MAPK pathway, HRAS was decreased and JUN and MYC were increased. JUN mRNA was decreased and, as JUN transcription is autoregulated by JUN protein (45), and JUN heterodimerizes with Meq. We suggest that even though total JUN protein was increased in CD30 ${ }^{\text {hi }}$ lymphocytes, it is not available for autotransactivation, an alternative possibility is that as JUN protein is stabilized by post-translational interactions with Meq, the JUN mRNA may not actually reflect the total JUN protein levels [39].

Activated PI3K phosphorylates AKT, which in turn activates IKKA, MTOR (FRAP1) and MDM2 and inhibits FKHR, CASP9, BAD, p27 and p21 genes [40-42]. IKKA, MDM2, CASP9 increased, though FKHR, p27, p21, MTOR (FRAP1) did not. PTEN inhibits PI3K signaling in the absence of growth factors, and STK11 (LKB1) inhibits MTOR activity when ATP is low [40]. Consequently, cells lacking functional PTEN or STK11 exhibit deregulated, but constitutive, signaling to
MTOR, resulting in cancer $(46,47)$. Though PTEN protein was not differentially expressed, STK11 protein (a tumor suppressor) decreased. From an antigrowth signal perspective, RB1 sequesters the E2F transcription factors transcriptionally-repressing genes essential for G1 to $\mathrm{S}$ phase cell cycle progression [42,43] and RB1 was decreased suggesting increased cell cycle progression in $\mathrm{CD} 30^{\text {hi }}$ lymphocytes supporting our previous work [15].

b) Cell cycle and PCD are dysregulated: Cell cycle regulation and $\mathrm{PCD}$ are intimately linked. The protooncogenic WNT proteins were increased and WNT activation leads to CTNNB protein nuclear translocation. CTNNB also increased and was $80 \%$ nuclear. Canonically, CTNNB translocation results in TCF-mediated activation of the proto-oncogene MYC (pro-cell cycle/anti-PCD), anti-PCD protein SURVIVIN and the G1/S-specific cyclin-D1 (CCND1) $[44,45]$. BCL2 blocks apoptosis in many diverse cancers, and in-vitro work using a rodent fibroblast cell line, suggests that MDV Meq increases BCL2 mRNA [46], and proposed that this is important in MD lymphomagenesis. In our work from MD lymphocytes in vivo, BCL2 protein was unchanged suggesting that any BCL2 functionalderegulation may occur prior to the $\mathrm{CD} 30^{\mathrm{lo}}$ to $\mathrm{CD} 30^{\mathrm{hi}}$ transition in the lymphoma environment. HSP70 inhibits both the intrinsic and the extrinsic PCD mechanisms and is frequently increased in malignant tumors [47-50], Meq also co-localizes with HSP70 in the nucleus [49] where HSP70 mediates Meq's interaction with TP53 and CDK2 [49]. In agreement, we found HSP70 protein was increased and was 100\% nuclear. Decreased PENK increases anti-PCD-gene transcription [51] and PENK protein was decreased by half, and its nuclear distribution decreased by $70 \%$, suggest decreased PCD possibly mediated by Meq (see below).

c) Telomeres are dysregulated: Shortened telomeres promote PCD and the telomerase complex maintains telomere length in cancer [52]. The telomerase complex has two core components: telomerase RNA (TR; the template for telomere repeat synthesis) and the enzyme TERT. CD30 hi lymphocytes have $20 \%$ more nuclear TERT. Furthermore, POT1, a protein also required for telomerase maintenance [53,54], was also increased in CD30 ${ }^{\text {hi }}$ cells.

d) Angiogenesis is increased: Tumor cells can induce neo-angiogenesis or vasculogenesis [55], and proangiogenic VEGF was increased and anti-angiogenic MMP9 remained unchanged, suggesting endothelial cell proliferation and angiogenesis.

e) Metastasis is promoted: Metastasis a primary cause of cancer mortality and part of MD pathogenesis. 
Ezrin (EZR) is essential for metastasis [56] and is consistently increased in metastatic cancers [57]. EZR complexes with NF2, links membrane proteins and the actin cytoskeleton, and regulates cell survival, adhesion and migration [58]; it also complexes with CD44 [59] and MET [60,61] to promote metastasis. EZR, NF2, CD44 and MET were all increased suggesting that metastasis is more a function of CD30 ${ }^{\text {hi }}$, than CD30 ${ }^{\text {lo }}$, lymphocytes and this is consistent with human CD30 ${ }^{\text {hi }}$ lymphomas.

f) Immune evasion mechanisms are increased: MAN1A2, (which induces T-reg cell migration and prevents $\mathrm{T}$ cell priming [62]), was increased and this supports our previous contention that as neoplastic transformation proceeds, a T-reg-like phenotype is induced $[3,6,12]$. IRG1 protein and mRNA $(p<0.06)$ were decreased in the CD30hi cells. Expression of IRG1 mRNA is induced by pro-inflammatory cytokines and lipopolysaccharide after bacterial infection of macrophages/monocytes [63]. There is very limited published literature about IRG1's functions in lymphomas, however, recent studies in MD literature have suggested that IRG1 may be associated with apoptosis and is potentially proapoptotic [64]. By searching the EBI Gene Expression Atlas (http://www.ebi.ac.uk/gxa/) we found that IRG1 mRNA is decreased in some human and mouse lymphoid neoplasia datasets also-as is its regulator leukemia inhibitory factor (LIF; which was decreased at the protein level in our data). We speculate that both LIF and IRG1 are worthy of investigation in future for a role in neoplastic transformation and anti-apoptosis in MDV pathogenesis [64]. The data that we found in the EBI Gene Expression Atlas shows that such a mechanism may exist in human disease also, but this data has not yet been recognized, nor the hypothesis tested, by human medical research.

g) Epigenetic regulators are activated: DNA methyl transferases (DNMT1, DNMT3A and DNMT3B), histone acetyltransferase (HAT) and histone deacetylases (HDAC)] are implicated in human and MD lymphomas [65] and HDAC-8 and -10 mRNAs, and DNMT3B and HDAC9 proteins, were increased.

h) MDV proteins other than Meq are involved and have altered expression: The MDV DNA replication genes thymidine kinase and deoxyuridine triphosphatase (73-75) decreased, in agreement with MDV being latent; but, in addition to Meq being increased, so were the envelop glycoproteins D, I, K, the major capsid protein and nuclear egress lamina protein all are structural proteins important for MDV horizontal transmission. This supports our previous work that CD $30^{\text {hi }}$ lymphocytes have the highest load in lymphomas [66] and suggests lateral MDV cellcell transmission within the lymphoma. We speculate, that MDV, like EBV [67] has more than one "latency program" and that the immunosuppressive lymphoma environment "permits" MDV to produce more proteins than it would in other environments. We also suggest, based on our data above, that, as in EBV [68], epigenetic regulation plays a role in latency programs.

\section{Biological processes associated with neoplastic transformation and immune-evasion}

At a higher level, the Gene Ontology (GO) allows explicit modeling not limited by canonical pathways [69]. We compared $\mathrm{CD} 30^{\mathrm{hi}}$ and $\mathrm{CD} 30^{\mathrm{lo}}$ lymphocyte proteomes, using quantitative $\mathrm{GO}$ biological process (BP) modeling (Figure 2A), for the biological processes inherent in neoplasia as described [3]. Although both the CD30 hi and CD30 lo lymphocytes have pro-neoplastic phenotypes (i.e. pro-cell activation, pro-angiogenic, anti-PCD, pro-cell
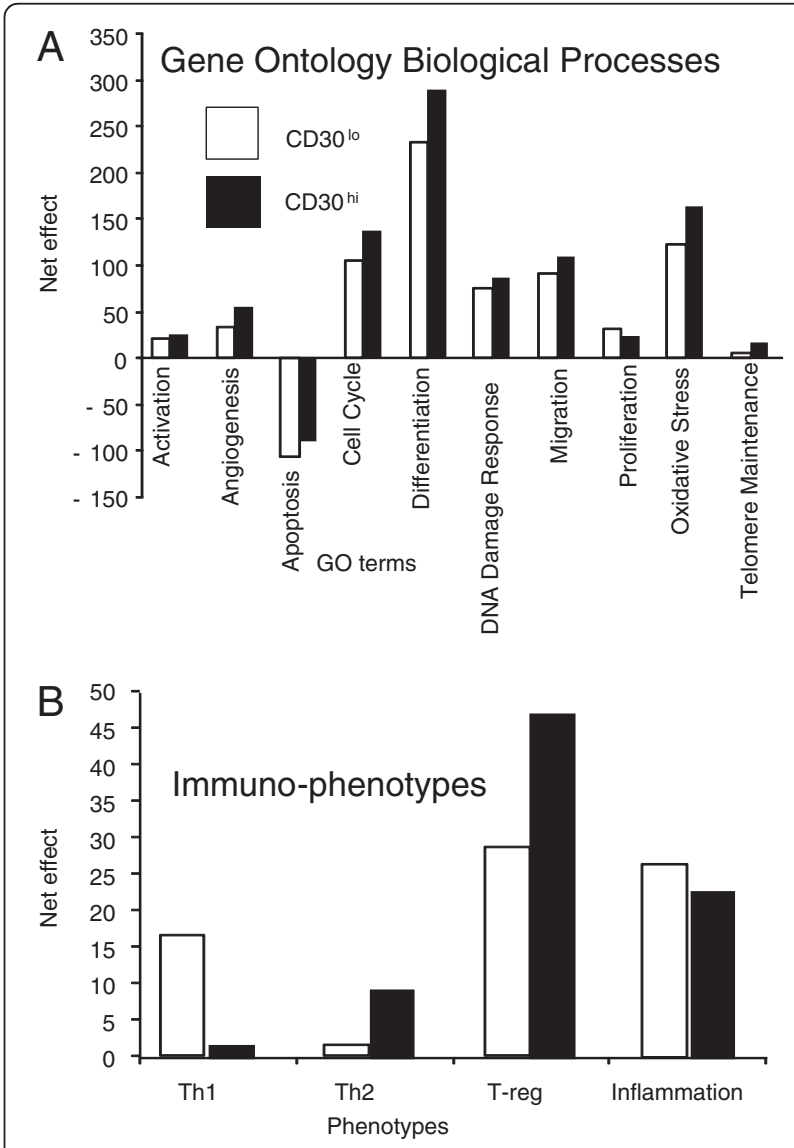

Figure 2 Proteomics based Gene ontology (GO) based quantitative modeling of cellular immunophenotypes of $\mathrm{CD} 30^{\circ}$ and $\mathrm{CD} 30^{\text {hi }}$ cells. Quantitative modeling of the $\mathrm{CD}^{\mathrm{lo}}$ and $\mathrm{CD} 30^{\text {hi }}$ lymphocyte proteome by Gene Ontology Biological Processes (A) and immunophenotype using GO-modeler [12] as described in methods [3]. 
cycle, pro-differentiation, pro-DNA damage response, pro-migration, pro-proliferation, pro-oxidative stress and pro-telomerase maintenance) the $\mathrm{CD} 30^{\text {hi }}$ cell proteome is more pro-neoplastic than the $\mathrm{CD} 30^{\mathrm{lo}}$.

Next, we compared the CD $30^{\text {hi }}$ and $\mathrm{CD} 30^{\text {lo }}$ lymphoma cell immune-phenotypes [6,12] (Figure 2B). We have identified the MD lymphoma microenvironment as predominantly T-reg-like [6] but did not differentiate which lymphocytes were contributing to the phenotype. Here we show that the $\mathrm{CD} 30^{\mathrm{hi}}$ and $\mathrm{CD} 30^{\mathrm{lo}}$ cell proteomes have similar T-reg-like phenotypes and the $\mathrm{CD} 30^{\text {hi }}$ lymphocytes are more Th-2-biased, but less Th-1 and proinflammatory-biased, than the CD $30^{\text {lo }}$ lymphocytes. This is consistent with a model of increased CD30 expression and signaling promoting immune-evasion $[9,70]$.

\section{Transcriptional regulation}

To identify potential direct transcriptional proteome regulation, we used the $44 \mathrm{~K}$ Agilent chicken microarray $[71,72]$ to quantify mRNA and micro (mi)RNA (Additional file 2) isolated from the same CD30hi and $\mathrm{CD} 30^{\text {lo }}$ lymphocytes which were used for proteomics and compared transcriptional fold changes with protein fold changes (Figure 3A; Additional file 3). Overall there was poor fold change correlation between mRNA and protein for 4592 host gene products $\left(R^{2}=0.0007\right)$. Next, to identify the key regulatory proteins responsible for neoplastic transformation, all the gene products which were differentially expressed in the same direction at both mRNA and protein levels were selected for further analysis. There are 88 gene products whose mRNA and protein fold changes were both significant and directionally consistent with each other (i.e. concordant) and these have an overall positive correlation (Figure 3B, $R^{2}$ $=0.5581$ ). Of these, on cross referencing with the published literature, revealed that BRCA2, CD30, CD40L, CST3 and PENK are known to be involved in human CD30 ${ }^{\text {hi }}$ lymphomas [17,51,73-79] and, except for CD30, all had decreased expression in CD30 ${ }^{\text {hi }}$ cells. BRCA2 is involved in error-free DNA-damage repair and decreased BRCA2 expression results in erroneous joining of DNA breaks [73]; CD30 is over-expressed in all human HL and some NHL [74,80]; CD40L prevents caspase-dependent and -independent PCD in HL cell lines [75]; CST3 is secreted by neoplastically transformed cells [76], inhibits neovascularization [81] and, via its inhibitory effect on cathepsin $B$ and $S$, inhibits tumor invasion and metastasis [82] and is a biomarker in humans for NHL relapse [77]. CST3's mRNA and protein decrease in MD CD30 hi lymphocytes is consistent with human and murine lymphomas [77-79] and decreased CST3, enhances angiogenesis, tumor burden, tumor cell proliferation and tumor invasion [83] and also leads to increased expression of pro-neoplastic growth factor like IGF1 and FGF1 in mice [84]. In cells over-expressing NF- $\mathrm{kB}$, and in coordination with TP53, PENK induces PCD [51], and so its decreased expression favors neoplasia.

Specific GO-based BP modeling of these 88 concordantly-expressed genes shows that they are involved in BPs known to be perturbed in, and central to, neoplastic transformation (Figure 3C): $25 \%$ are involved in proliferation, $20 \%$ in cell cycle and 10\% in regulating PCD, cell-cell adhesion (essential for metastasis), innate and adaptive immunity, oxidative stress, DNA damage response and glucose metabolism.

We next ranked the genes based on their mRNA: protein expression correlation, and then grouped them into pentiles and compared the distribution of BP by pentile (Figure 3D-i). Across the five pentiles gene expression regulation was the most dominant $\mathrm{BP}$; the next two biggest $\mathrm{BP}$ groups, consistent across the five pentiles, were proliferation and cell cycle. Both proliferation and cell cycle are central to lymphoblastoid cell physiology and neoplastic transformation. The proliferation: cell cycle and proliferation: PCD ratios were both 4.5 in pentile 1 . In contrast the mean ratios for the other four pentiles were 1.4 (range 0.6 to 3 ). The high correlation between mRNA and protein expression, coupled with predominance of genes involved in cell proliferation in pentile 1 (compared to other four pentiles), suggested that pentile 1 genes may be transcriptionally regulated via Meq and this would favor neoplastic transformation.

We next identified the numbers of putative canonical MDV Meq binding sites (searched for the core AP-1, MERE I and MERE II motifs as described in [85]) in each of the 88 concordantly-expressed genes' promoters (2.5 Kb 5' of the ATG) as described [86]. Genes in pentile 1 (with mRNA: protein expression ratios closest to 1:1) have more Meq binding sites in their promoters than those in the other pentiles, which do not differ from each other (Figure 3D-ii, Additional file 4). Of the five concordant genes previously implicated in lymphomagenesis in other species, BRCA2, CD30, CD40LG, and PENK are in pentile 1 with a group mRNA:protein expression correlation $\left(R^{2}\right)$ of 0.92 , suggesting direct transcriptional regulation by Meq. In contrast, CST3 is in pentile 4 with a large decrease in protein but small decrease in mRNA. It is possible that CST3 is regulated at the level of miRNA; an alternative possibility is that CST3 is a secreted protein so a small decrease in mRNA could result in a large decrease in cellular protein and, consistent with our observation, most CST3 was located in the predominantly soluble differential detergent fraction 1 . Notably, IRG1 was in pentile 1 , and has the most Meq binding sites of all the concordant genes (51), all of which are MERE II binding sites, suggesting Meq induced transcriptional repression, and a central role in 


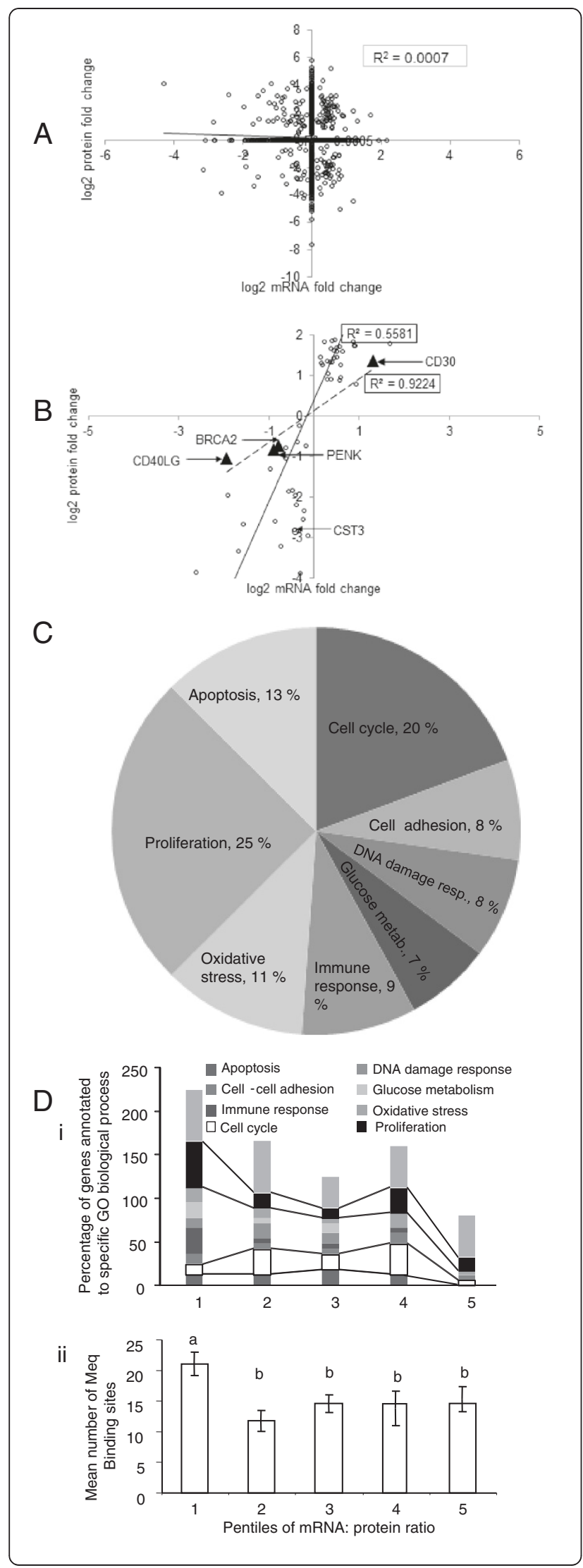

Figure $3 \mathrm{mRNA}$ and protein correlation and GO based modeling of 88 concordantly expressed host gene products. Overall correlation $\left(R^{2}=0.0007\right)$ of protein and mRNA fold changes in CD30 ${ }^{\text {hi }}$, compared to CD30 lo lymphocytes $((\mathbf{A}) ; n=4592)$. Overall correlation for gene products differentially expressed in the same direction at both mRNA and protein levels showing higher correlation ( $\mathrm{n}=88, R^{2}=0.5581$ ). The triangles indicate genes known to be involved in $C D 30^{\text {hi }}$ lymphomas, and have mRNA: protein correlation close to $1\left(R^{2}=0.92\right)$. CST3 is also involved in in CD30 hi lymphomas but has very low mRNA: protein correlation. (B). Gene Ontology (GO) Biological Processes (BP) associated with the concordantly-expressed gene products indicates involvement in cellular processes perturbed in neoplastic transformation (C). Concordant gene products were ranked based mRNA: protein correlation and then grouped into pentiles and distribution of GO $\mathrm{BP}$ by pentile were compared. Cell cycle and proliferation are disproportionately represented in pentile 1 (D-i). Pentile 1 genes have more putative Meq binding sites in their promoters than genes in the other pentiles (mean \pm sem) (D-ii).

MD neoplasia. Overall, the data suggests that the genes in pentile 1 are critical for neoplastic transformation.

miRNAs are non-coding post transcriptional repressors potentially important in neoplasia and we identified 152 expressed chicken miRNAs (Additional file 2). Of these, nine (gga-mir-1b, gga-mir-7, gga-mir-7b, gga-mir10b, gga-mir-31, gga-mir-130b, gga-mir-204, gga-mir215, gga-mir-489) are increased, and five (gga-mir-223, gga-mir-124b, gga-mir-140, gga-mir-183, gga-mir-222a) are decreased in CD30 ${ }^{\text {hi }}$ cells. In MDV infected CEFs, gga-mir-29b,-196,-133a,-10b,-30d were increased, and gga-mir-let-7a, 7b, 7f and gga-mir-1a, mir-130a were decreased [87]; of these only gga-mir-10b was increased in our data. This suggests that the in vivo lymphoma environment where MDV is "latent" is functionally quite different from a lytic fibroblast culture. In vitro, ggamir-221 and gga-mir-222 inhibit expression of CDK inhibitor protein $\mathrm{p} 27 / \mathrm{KIP} 1$, but $\mathrm{p} 27 / \mathrm{KIP} 1$ protein was increased in the MDV transformed lymphoblastoid cell line MSB-1 [88]. In our results gga-mir-221 was not differentially expressed and gga-mir-222a was decreased: and this is consistent with our data that $\mathrm{p} 27 / \mathrm{KIP} 1$ protein is not differentially expressed. gga-mir-26a inhibited IL-2 mRNA and was decreased in seven MD transformed cell lines $[89,90]$, but again in our dataset, neither gga-mir-26a nor IL-2 were differentially expressed and neither was IL-2 protein.

We used the miRDB $[91,92]$ to identify novel miRNA targets (Additional file 2), and we found that the 9 different miRNAs that increased in $\mathrm{CD} 30^{\text {hi }}$ lymphocytes target several genes associated with neoplastic processes (Additional file 2): gga-mir-204 targets FAS apoptosis inhibitory molecule 2, RAB22A (a RAS oncogene family member) and HDAC 9; gga-mir-489 targets FAS associated factor 1 (FAF1) and gga-mir-7 targets RAS related viral oncogene homolog 2. Except FAF1 (which was 
unchanged) none of these proteins were identified and so we cannot confirm the upregulated miRNA's potential effects on neoplasia in CD30 ${ }^{\text {hi }}$ cells. Notably however, gga-mir-183 which targets EZR mRNA (which did not change), was decreased and EZR (important in metastasis) protein increased; i.e. we suggest that one reason for the increase in EZR protein is decreased gga-mir-183 translation-inhibition.

\section{$\mathrm{CD} 30^{\text {hi }}$ lymphocytes have increased levels of activated NF-KB}

Constitutive NF- $\mathrm{kB}$ activation is a proposed mechanism by which overexpressed CD30 induces neoplastic transformation in human $\mathrm{HL}$ and NHL and in MD [18]. Our global proteomics modeling data (Figure 1), Ingenuity Pathway analysis, and mRNA-protein correlation data (Figure 3) further suggested a direct role of Meq and NF- $\mathrm{KB}$ in MD transformation. CD30 activates $\mathrm{NF}-\mathrm{KB}$ via both canonical and non-canonical pathways and both ligand-dependently and -independently [11]. In the canonical pathway, ІкB inhibitors, ІкB $\alpha$, ІкB $\beta$, and $I_{\kappa} B \in$ (not identified in chicken) are phosphorylated by IKB kinases (IKK) and ubiquitinated by ubiquitin ligase (BTRCP). Proteasomal degradation of ІкB inhibitory proteins releases NF- $\mathrm{kB}$ dimers, which translocate to the nucleus and transactivate target genes [93]. In the non-canonical pathway, p100 (NF-kB2 precursor protein) acts as IKB inhibitory molecule and an IKK $\alpha$ homodimer acts as the main activator: IKK $\alpha$ phosphorylates $\mathrm{p} 100$, resulting in proteasomal degradation of inhibitory C-terminal domain ( $\mathrm{I} \mathrm{B} \delta$ ), which generates the p52 subunit (functional NF- $\mathrm{kB} 2$ protein) and dimerizes with RelA or RelB to form functional NF- $k B$ dimers [94].

We found that NF-kB p50 (functional NF-kB1), p65 (RelA) and RelB and IKK $\alpha$ proteins all increased in $\mathrm{CD}^{\mathrm{hi}}{ }^{\mathrm{l}}$ lymphocytes (Figure 4A) and most p50 and all p65 protein (which form the most common and abundant classical dimers) were nuclear (Figure 4B, Additional file 1). NF- $\mathrm{kB}$ signaling is controlled by nega-

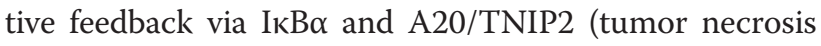
factor alpha-induced protein 3 [TNFAIP3] in chicken) transcriptional induction [95] and we found TNFAIP3 mRNA and protein unchanged but ІкB $\alpha$ mRNA decreased, suggesting that this negative feedback mechanism is suppressed. The TNFAIP3 and I $\mathrm{B} \alpha \alpha$ promoters have 18 (all MERE II) and 9 (3 MERE I and 6 MERE II) predicted Meq-binding sites, respectively, which suggest that MDV has evolved to maintain NF- $\mathrm{kB}$ activation. Not only do CD30 ${ }^{\text {hi }}$ lymphocytes have more of all NF$\mathrm{\kappa B}$ isoforms but more are nuclear (Figure 4B, Additional file 1), again suggesting NF- $\mathrm{BB}$ activation. Furthermore in CD $30^{\mathrm{hi}}$ lymphocytes, most IKK $\alpha$ is phosphorylated at the canonical residues that regulate proteasome- mediated degradation $[96,97]$ and destabilization [98100], whereas the opposite occurred for IKK $\alpha$ in CD30 ${ }^{\text {lo }}$ lymphocytes (Figure 4C, Additional file 1).

\section{NF-кB transactivates Meq transcription in vitro}

Because we proposed a feed-forward loop model of increasing Meq and CD30 expression [18] and our global analysis suggests that NF- $\kappa B$ is central in MD lymphomagenesis, we tested NF- $\mathrm{KB}$ isoforms' transactivation potential on the Meq promoter using in vitro transcription reporter assays $\left(1 \mathrm{~Kb} 5^{\prime}\right.$ of the Meq ATG; MDV strain RB-1B). We cloned genes RELA [p65], NFKB1 [p105/p50] and NFKB2 [p100/p52] and MEQ (RB-1B) into expression plasmids. SOgE cells [101] were transfected with the reporter plasmid alone or in combination with plasmids expressing different $\mathrm{NF}-\mathrm{kB}$ isoforms and/or Meq, and transcription was quantified by QPCR. The three NF-kB isoforms differentially transactivated the Meq promoter (Figure $5 \mathrm{~A}$ ): p52 was less than p50 and RELA (p65) alone, which produced similar transcription and were less than $\mathrm{p} 50$ and RELA (p65) together (in vivo p50 and p65 form the classical dimer). Meq alone transactivated the Meq promoter to similar levels as the positive control cytomegalovirus promoter and, when used together with different NF- $\mathrm{kB}$ isoforms, except in the p50-p65 dimer, it further increased transcription. This finding suggests that neoplastic transformation in MD depends fundamentally on CD30 signaling, and may explain why MD neoplastically-transformed cell survival (like that of many human herpesvirus induced lymphomas) critically depends on the lymphoma environment $[6,12,15]$, as well as why MDV co-opted the CD30 signaling pathway.

\section{Meq-dependent differential CD30 promoter transcription}

It would be reasonable that differences in the CD30 promoter could confer differences in Meq-induced activation or repression of the CD30 gene and is of interest to us because of chicken genotype differences to MD lymphomagenesis after MDV infection. To measure Meq-induced CD30 transcription on different CD30 promoters, we first cloned and sequenced CD30 promoters (2431-2438 bp 5' to the ATG) from two MDresistant (lines $6_{1}$ and $\mathrm{N}$ ) and four MD-susceptible (line $7_{1}, 7_{2}, 15 \mathrm{I}_{5}$, and P) genotypes of chickens and sequenced these. An unrooted phylogenetic tree (Figure 5B) of these sequences matched the chicken line breeding history [102]. Lines 6, 7 and 15 are part of 15 lines developed to study the genetics of avian neoplasia [102]. Line 6 and 7 share common ancestors and this is emulated in their phylogenetic closeness in our data. Line 15 is also genetically related to lines 6 and 7 and some line 15 birds were isolated and interbred to produce the 15I 
A Increased protein expression in CD $30^{\text {hi }}$ cells Decreased protein expression in CD $30^{\text {hi }}$ cells Not differentially expressed

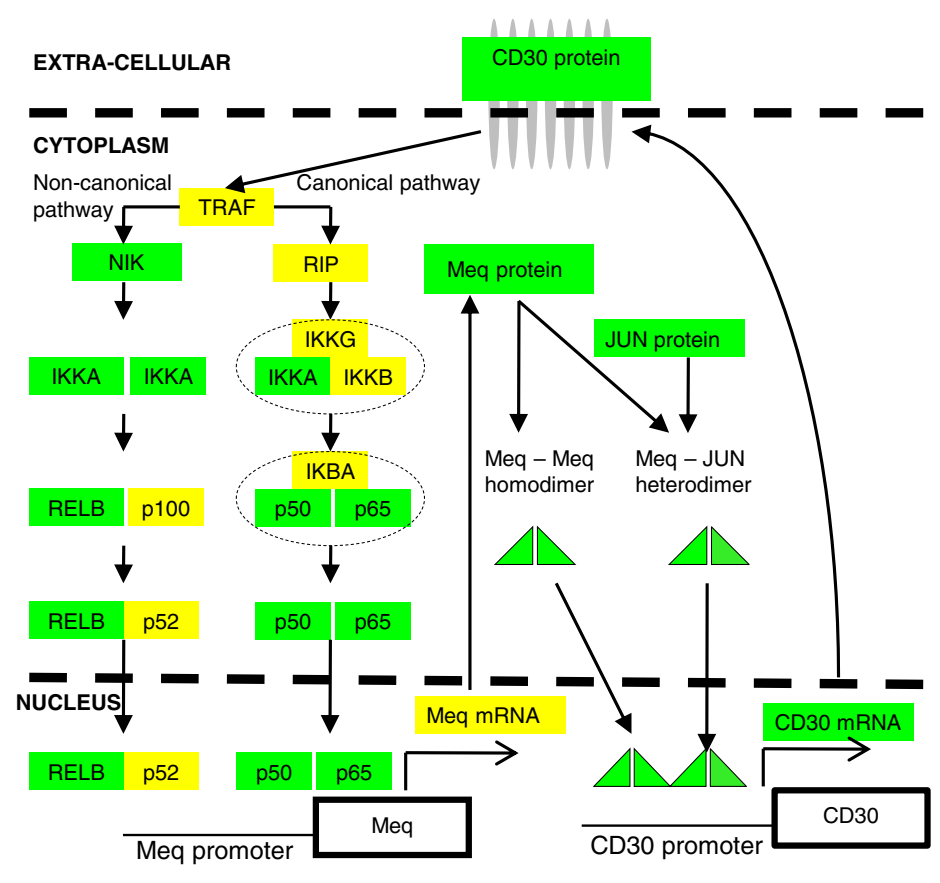

B

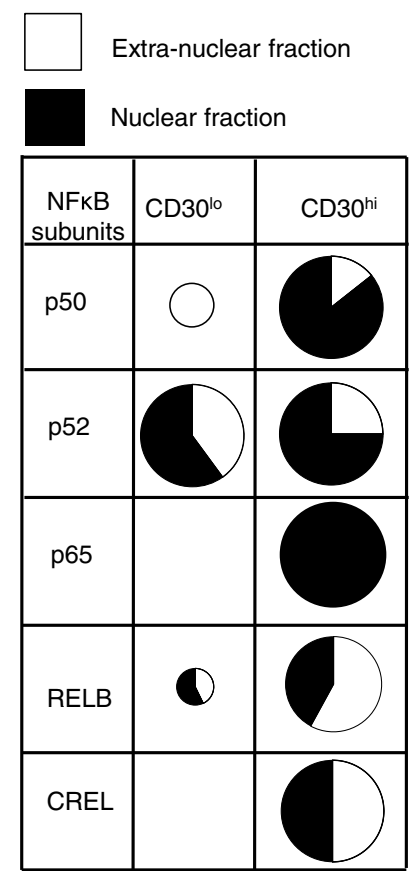

C Unphosphorylated

Phosphorylated

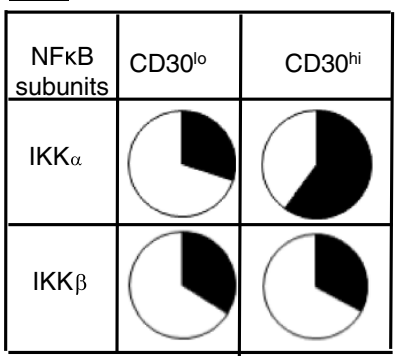

Figure 4 Schematic diagram of the hypothesized Meq-CD30- NF-KB feed forward loop, subcellular localization and phosphorylation status of different isoforms of NF-KB. Schematic diagram of hypothesized Meq-CD30-NF-KB feed forward loop and showing differential expression of NF-kB isoforms (A). Comparison of the amount and sub cellular localization of NF-KB isoforms: circle size proportionately portrays relative protein amount; equal size indicates no differential expression at $\mathrm{P}<0.05$ (B). In $\mathrm{CD} 30^{\text {hi }}$ lymphocytes most IKKa is phosphorylated at the canonical residues that regulate proteasome-mediated degradation and destabilization, whereas in CD30 lymphocytes most IKKa and IKK $\beta$ is unphosphorylated at these same residues (C). 


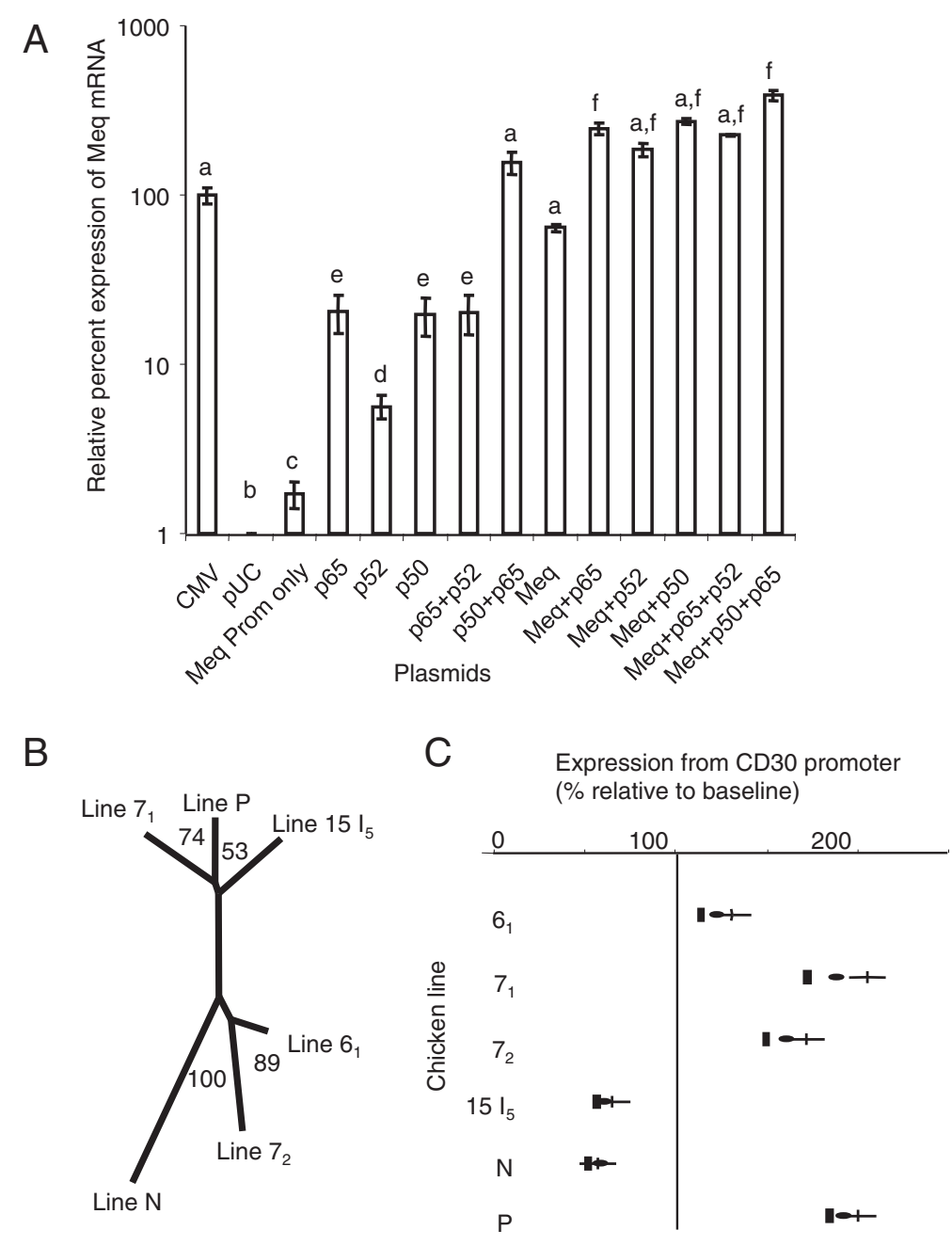

Figure 5 QPCR based results of various transcription reporter assays and phylogenetic tree constructed from CD30 promoter sequences of $M D$ resistant and susceptible genotypes. QPCR results from in vitro transcription assay comparing the efficacy of NF-KB subunits and Meq combinations on transcription from the MDV RB-1B Meq promoter (mean \pm sem); a-f indicate statistical differences (A). Unrooted phylogenetic tree constructed from CD30 promoter sequences for MD-resistant $\left(6_{1}, \mathrm{~N}\right)$ and MD-susceptible genotypes $\left(7,7_{2}, 15 I_{5}\right.$ and P) (B). Quantitative effects of Meq on transcription from the MD resistant and susceptible genotypes' CD30 promoter (mean, $95 \% \mathrm{Cl})(\mathbf{C})$.

sublines. Further sublines (e.g. $6_{1}, \mathrm{~L}_{1}, \mathrm{~L}_{2}$ and $15 \mathrm{I}_{5}$ ) were produced by further inbreeding. Notably, line $7_{1}$ was accidentally crossed with $15 \mathrm{I}_{5}$ [102,103], and we independently identified this event in our phylogenetic tree, which places Line $7_{1}$ closer to Line $15 \mathrm{I}_{5}$ than Line $7_{2}$. Lines $\mathrm{N}$ and $\mathrm{P}$ are non-inbred lines developed independently to study MHC class I-based resistance and susceptibility to MD $[103,104]$.

After cloning into an expression plasmid, each CD30 promoter was used in in vitro transcription assays using a Meq-expressing plasmid. Meq altered transcription from all CD30 promoters' alleles (Figure 5C) - increasing expression in MD-susceptible lines $7_{1}, 7_{2}$ and $\mathrm{P}$, but decreasing in the MHC MD-resistant line $\mathrm{N}$ and the very late lymphoma forming [9] line $15 \mathrm{I}_{5}$. MD resistant line $6_{1}$ had a small increase in transcription. The trend is that CD30 promoter transcription is associated with MD lymphoma resistance and susceptibility and that Meq has host genotype-dependent transcriptionalactivation or repression from the CD30 promoter. However, although there are 56 single nucleotide polymorphisms (SNPs) between the lines' promoter sequences (SNPs; NCBI accession numbers: EU000367EU000372), none occur in the predicted canonical Meq binding sites [85] and sequences other than these previously-described Meq binding sites must be functional. We identified one SNP at position 1754 bp in $15 \mathrm{I}_{5}$ and $1755 \mathrm{bp}$ in line $\mathrm{N}^{\prime}$ of the ATG as a candidate; transcription factor binding prediction [105] identifies the corresponding region in all lines as an AP-1 binding site and we suggest that this SNP could be responsible for differential function. 


\section{Meq interacts directly with proteins central to lymphomagenesis}

Meq's functions are modulated by its interacting partners. Here we wanted to identify which proteins were involved with $\mathrm{Meq}$ in the context of DNA binding and so we used chromatin immunoprecipitaion (ChIP) using anti-Meq antibodies (rather than traditional immuneprecipitation), followed by 2D LC-MSMS. We used MSB-1 MDCC cells as a model for tumor cells. We identified 31 proteins (PRIDE Accession \# 14847-14852, Additional file 1). We used these 31 proteins and included previously identified interacting proteins (RB1, TP53, CTBP, HSP70, JUN, FOS, CDK2, CCND1), to produce theoretical Meq interactome model. From these, and using binding proteins from literature, we produced a Meq interactome model (Figure 6A). Using GO BP annotations for all the proteins that we modeled in the network, we next generated a GO BP-based functional interaction network (Figure 6B). This model suggests how Meq could interact with proteins associated with BPs critical to tumor formation such as cell growth, development, apoptosis, stress, immunity, transcription, cell adhesion, energy metabolism, protein metabolism and transport.

\section{Discussion}

Evidence supporting a direct mechanistic connection between inflammation and cancer has been mounting over the last decade [106]. The very early pre-lymphoma MD lesion microenvironments are highly inflammatory [6]. $\mathrm{NF}-\kappa \mathrm{B}$ is one of the central inflammatory mediators that is often, and diversely, associated with neoplastic transformation [107] and is a key component of the transformation pathways employed by some herpesviruses. The KSHV latency-associated proteins vGPCR and vFLIP, maintain a sustained level of activated NF- $\mathrm{kB}$ by interacting with IKK protein complex and micro RNA clusters (miR-K1) which inhibit $I_{\kappa} B \alpha$ protein expression, thus inhibiting the lytic cycle, inducing the latency and transformation [108-111]. In EBV positive HL the transformed cells overexpress CD30, CD40, RANK receptors and their cognate ligands are expressed on surrounding stromal cells. Ligand and receptor interaction (or sometimes ligand independent signaling) activates downstream signaling and activation of NF- $\mathrm{KB}$ occurs [112]. EBV encoded LMP-1 protein mimics the activated CD40 receptors and results in spontaneous NF- $\mathrm{kB}$ activation [67]. Our "omic" and reductionist experiments in this work suggest that MDV has also evolved to directly perturb the NF- $\kappa B$ signaling pathways while in viral latency.

In vitro MDV Meq induced CD30 expression and persistently activated NF- $\mathrm{KB}$ and ex vivo-derived CD30 ${ }^{\mathrm{hi}}$ lymphocytes have increased and activated NF-kB protein. Not only does Meq enhance its own transcription (as previously described [20]) but it also augments NF$\kappa \mathrm{B}$ transcription. We also suggest that $I_{\kappa} \mathrm{B} \alpha$-mediated negative feedback, which controls NF- $\mathrm{B}$ activation, is hypoactive in $\mathrm{CD}{ }^{\mathrm{hi}}$ cells. This is consistent with evidence that proinflammatory cytokines induce NF- $\mathrm{kB}$ inducing kinase (NIK), which preferentially phosphorylates IKK $\alpha$ over IKK $\beta$ to activate NF- $\mathrm{B}$ [113] and, while recent evidence suggests that $I K K \beta$ is primarily activated in response to pro inflammatory cytokines and microbial products, IKK $\alpha$ regulates the alternative pathway of NF$\kappa \mathrm{B}$ activation in lymphoid malignancies [114]. IKK $\alpha$ is also preferentially activated by the members of TNF receptor family [115]. Inducing persistent NF- $\mathrm{kB}$ signaling through specific oncoproteins has been demonstrated for human oncogenic viruses, including EBV, human $\mathrm{T}$ cell leukemia virus type 1, and KSHV [116]. Notably, EBV LMP-1 effects NF- $\kappa$ B activation through the NF- $\kappa B$ essential modifier protein which, with IKK $\alpha$ and IKK $\beta$ protein, comprises the IKB kinase (IKK) complex [117] and we speculate that MDV (possibly via Meq) has evolved to similarly target the IKK complex.

Regardless, our data supports our hypothesized model that Meq initiates a self-reinforcing CD30 signaling cycle resulting in constitutive and aberrant NF- $\mathrm{KB}$ activation and subsequent neoplastic transformation. Herpesviruses co-evolve with their hosts and and the last common ancestor between EBV and MDV was at least >300 M years ago; MDV, EBV and KSHV have separately evolved in different target cells the same fundamental result by targeting the NF- $\mathrm{B}$ pathway. Furthermore both MDV Meq and EBV LMP-1 [118] are expressed as proteins during viral latency and their hosts mount specific (but weak) cytotoxic $\mathrm{T}$ cell responses against them $[18,119,120]$. This large evolutionary distance, combined with the risk incurred by inducing an immune response, suggests that perturbing NF- $\mathrm{kB}$ confers a strong evolutionary advantage and is further evidence consistent with NF- $\mathrm{kB}$ essentiality to neoplasia in general.

Meq is essential for MD lymphomagenesis [21,121] and promotes neoplastic transformation, anchorageindependent growth, cell-cycle progression, and antiapoptotic activity [46,122-124]. Our in vitro experiments support Meq's previously demonstrated transcriptional regulation of CD30 [18], and, also show that the transcriptional profile generally follows genetic resistance and susceptibility to MD. A similar phenomenon has been observed in the CD30 over-expressing human cutaneous lymphoproliferative disease lymphomatoid papulosis [4,125]: allelic differences in the CD30 transcription are due to polymorphisms in the human CD30 microsatellite repressor element (located $-1.2 \mathrm{~kb}$ and $-336 \mathrm{bp}$ of the CD30 promoter) and are associated with disease progression to lymphoma [125]. 
Increased protein expression in CD30 hi cells

Decreased protein expression in CD $30^{\text {hi }}$ cells

Not differentially expressed

Not identified in proteomics or ChIP dataset

\# Identified only in proteomics dataset

\$ Identified both in proteomics and ChIP dataset

4 Canonical interactions provided by Ingenuity Pathway Analysis

4 Interactions based on ChIP results

$\uparrow$ Interactions based on literature

A

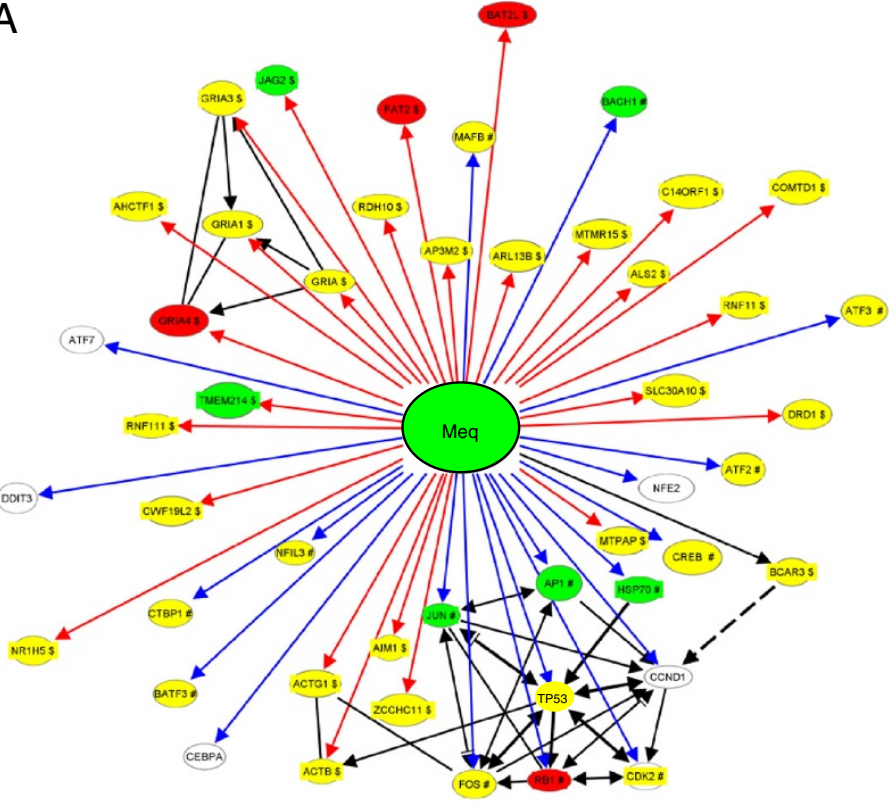

B

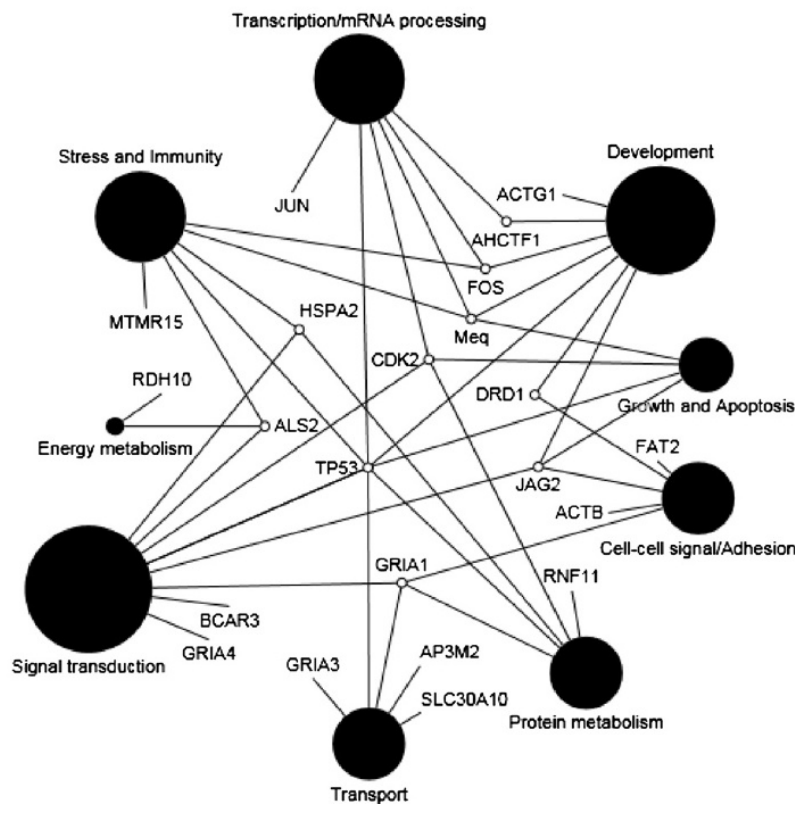

Figure 6 (See legend on next page.) 
(See figure on previous page.)

Figure 6 Meq interactome showing previously published and novel interactions identified by ChIP experiments and GO based modeling of Meq interacting proteins. Meq interactome based on combined data from proteins identified by chromatin immunoprecipitation (ChIP) experiments (see Methods) and published literature. Differential expression is shown for proteins identified by ChIP. (A). Meq interactome converted to a GO functional network showing the physiological processes that Meq directly affects are consistent with neoplasia. Circle size represents effect size based on numbers of proteins associated with that GO annotation (B).

Non-transformed cells are common in lymphomas of all species, and often they form the majority cells in lymphomas. Our work suggests that many of these non-transformed cells are likely not immune responding cells in MD [15], but are pre-neoplastic and actively transforming. Regardless, an immunosuppressive tumor microenvironment is critical in lymphomagenesis $[6,8,12,14,15,126,127]$. In EBV-positive HL, the lymphoma microenvironment is T-reg cell rich and the transformed cells secrete immunosuppressive cytokines and chemokines like IL10, CCL5, CCL20, and CXCL10. These cytokines and chemokines (may not always match classical T-reg cytokine profiles [128-130]), attract non-transformed cells $[131,132]$ to the site of lymphomagenesis. Similarly, in MD, a recent study has shown interactions between vIL-8 (a chemotactic factor) and peripheral CD4 + CD25+ T cells (closely resemble T-reg phenotype) [12,133], and suggested that vIL-8 may enhance the recruitment of T-reg cells to the MDV lymphoma microenvironment, which would further induce immunosuppression and enhance lymphomagenesis, supporting our previous observations $[6,12]$. Here, we have expanded on our previous work [6] and show that both components of lymphoma microenvironment, the $\mathrm{CD} 30^{\mathrm{hi}}$ and $\mathrm{CD} 30^{\mathrm{lo}}$ cells have an overall T-reg-like phenotype and suggest that $\mathrm{CD} 30^{\text {lo }}$ lymphocytes are direct antecedents of $\mathrm{CD} 30^{\text {hi }}$ lymphocytes.

Overall, and in the context of understanding mechanistic details of $\mathrm{CD} 30^{\mathrm{hi}}$ lymphomagenesis, our results provide direct ex vivo-derived support in a natural animal model for the in vitro results in other species, which propose that ligand-independent and -dependent CD30 signaling-induced constitutive activation of NF- $\mathrm{KB}$ is a mechanism of neoplastic transformation in Hodgkin's disease antigen over-expressing lymphomas [17].

\section{Conclusions}

Here we identify the neoplastic and non-neoplastic component of lymphoma microenvironment using transcriptomics and proteomics followed by Systems Biology modeling to generates specific hypotheses and then tests these using reductionist methods. This work provides evidence that MD neoplastic transformation is a continuum and the $\mathrm{CD} 30^{\mathrm{lo}}$ lymphoma cells are in various stages of neoplastic transformation towards $\mathrm{CD} 30^{\text {hi }}$ phenotype. We hypothesized that MDV uses its Meq oncogene to activate CD30 transcription to achieve constituent NF- $\mathrm{kB}$ signaling resulting in cellular instability and a neoplastic phenotype. Our results show that Meq, $\mathrm{CD} 30$ and NF- $\mathrm{kB}$ proteins are overexpressed in CD30 ${ }^{\mathrm{hi}}$ cells and that the majority of NF- $\mathrm{KB}$ is intranuclear suggesting an activated state. Using transcription reporter assays, we further show that NF- $\kappa B$ isoforms differentially activate Meq transcription, and Meq and NF- $\mathrm{kB}$ isoforms have additive effects. We also show that Meq transcriptionally activates or represses the CD30 promoter depending upon the host genotype from which the promoter is derived. Using ChIP and mass spectrometry we propose a new Meq interactome composed of proteins which are involved in various biological processes inherent in neoplasia. Overall, this study provides crucial insights into various molecular mechanisms of neoplastic transformation active within a heterogeneous lymphoma microenvironment in a natural animal model with functional immune system.

\section{Methods}

\section{RNA isolation and microarray experiments}

Lymphomas were isolated from white leghorn chickens infected with MDV GA/22 strain as described [9]. The $\mathrm{CD} 30^{\mathrm{hi}}$ and $\mathrm{CD} 30^{\mathrm{lo}}$ cells were separated using monoclonal antibody (mAb) AV37 using magnetic activated cell sorting (Militenyi Biotech) and the purity of sort was analyzed by flow cytometry as described [66]. RNA was isolated from 4 replicates of $10^{6} \mathrm{CD} 30^{\mathrm{hi}}$ and $\mathrm{CD} 30^{\mathrm{lo}}$ lymphocytes using the TRI Reagent ${ }^{\circledR}$ (Molecular Research Center). The quality of purified RNA was analyzed using the Agilent 2100 Bioanalyzer (Agilent Technologies) and RNA was quantified using the GeneSpec I spectrophotometer $[12,66]$. The microarray design and methods have been described in [71,72]. Briefly, a $44 \mathrm{~K}$ Agilent chicken microarray with dual color balanced design was used [71]. The genes on the array included whole chicken genome, 150 chicken microRNAs, [72,134,135], all known MDV and two avian influenza virus (H5N2 and H5N3) transcripts [72]. $500 \mathrm{ng}$ of total RNA was reverse transcribed into cDNA with a T7 sequence inserted in CDNA to drive the synthesis of complementary RNA (cRNA). The fluorescent labeled cRNA were purified, hybridized, washed and then scanned by Genepix 4100A scanner (Molecular Devices) with the tolerance of saturation setting of $0.005 \%$ [72]. 
The normalized data was analyzed using SAS 9.1.3 program (SAS Institute). An approximate F test on leastsquare means was used to identify the differentially expressed genes $(\mathrm{p}<0.05)$ [72]. Data has been deposited in GEO database, accession numbers (Samples: GSM689844, GSM689863, GSM689864, GSM689865, Series: GSE28034).

\section{Protein isolation and protein analysis by 2 dimensional liquid chromatography electro-spray ionization tandem mass spectrometry (2D LC ESI MS/MS)}

Proteins were isolated from three replicates from (from different birds) $10^{7} \mathrm{CD} 30^{\mathrm{hi}}$ and CD $30^{\mathrm{lo}}$ cells using differential detergent fractionation (DDF), trypsin-digested and analyzed by 2D LC ESI MS/MS using a LCQ Deca XP Plus (Thermo Fisher Scientific) as described [136]. The experimental mass spectra and tandem mass spectra were searched (Bioworks, 3.2, Thermo Fisher Scientific), against an in silico trypsin digested non redundant protein database which included all annotated chicken and MDV proteins, with search criteria as described [3]. Peptide identification used decoy database searching and only peptides identified with $\mathrm{p}<0.05$ were used for further analysis; the differentially expressed proteins were then identified at $\mathrm{p}<0.05$ as described [137]. Data has been deposited in PRIDE database accession numbers 14847-14852. We searched the mass spectra for evidence phosphorylation of the conserved canonical residues regulating proteasome-mediated degradation $[96,97]$ and destabilization [98-100] of inhibitor of nuclear factor kappa-B kinase (IKK)- $\alpha$ and IKK- $\beta$ exactly as for non-modified peptides except that we searched explicitly for an additional $80 \mathrm{Da}$ added to unphosphorylated amino acids [138,139] and calculated probabilities for phosphopeptides using decoy database searching, the degree of phosphorylation, as described $[137,139]$.

\section{Co-immmunoprecipitation of Meq interacting proteins}

Meq interacting proteins were identified by chromatin immunoprecipitation (ChIP) assays with polyclonal antiMeq antibody. MSB-1 cells were grown in Leibowitz's L15 and McCoy 5A media supplemented with fetal bovine serum $(15 \%)$, penicillin $(100 \mathrm{IU} / \mathrm{mL})$ at $37^{\circ} \mathrm{C}$. Cells $\left(10^{7}\right)$ were cross-linked with formaldehyde $\left(1 \%, 10 \mathrm{~min}, 37^{\circ} \mathrm{C}\right)$, which was added directly to the culture medium. The culture medium was removed and washed twice with ice cold phosphate-buffer saline (PBS) containing protease inhibitor cocktail (Sigma-Aldrich, P8340). ChIP was done using the Chromatin Immunoprecipitation Assay kit (Millipore, 17-295) exactly following manufacturer's recommendations. Immunoprecipitation was performed with anti-Meq polyclonal antibody (1:100), incubated overnight at $4{ }^{\circ} \mathrm{C}$. The DNA/Meq/antibody complexes were purified using Protein A-agarose/salmon sperm
DNA beads. The purified complex sample was reverse cross-linked separating the DNA from Meq and its interacting proteins. Proteins that were coimmunoprecipitated with Meq were analyzed and identified by 2D LC ESI MS/MS as described above.

\section{Plasmid construction}

The CD30 promoters (2431-2438 bp upstream from the ATG start codon) of six different chicken lines $\left(6_{1}, 7_{1}\right.$, $72,15 \mathrm{I}_{5}, \mathrm{~N}$ and $\mathrm{P}$ ) were amplified by PCR with Pfu polymerase (Promega) and primers CD30-F and CD30-R. The amplified promoters were ligated into $\mathrm{pCR}^{\circledR} 2.1$ TOPO $^{\circledR}$ (Life Technologies) producing $\mathrm{pCR}^{\circledR}$ 2.1-CD30 plasmids. The cytomegalovirus (CMV) promoter in the pd2EGFP-N1 plasmid (Takara Bio) was removed by digestion with XhoI and VspI; linear DNA was bluntended by T4 DNA polymerase and then self-ligated producing pd2EGFP $\triangle$ CMV. CD30 promoters were released from the $\mathrm{pCR}^{\circledR} 2.1-\mathrm{CD} 30$ plasmids by EcoRI digestion and ligated into EcoRI-linearized pd2EGFP $\triangle \mathrm{CMV}$ resulting in production of the six new expression plasmids pd2EGFP-CD30. The Meq promoter (1 kb upstream from the Meq start) of the virulent MDV-1 strain RB-1B was amplified by PCR with primers MEQ-F and MEQ-R. The promoter was first cloned into $\mathrm{PCR}^{\circledR} 2.1$ $\mathrm{TOPO}^{\circledR}$, then released by EcoRI digestion and re-cloned into EcoRI-linearized pd2EGFP $\triangle \mathrm{CMV}$ producing the reporter plasmid pd2EGFP-Meq. The chicken cDNA encoding the NF-kB p100 [140] was released from the cloning vector $\mathrm{pBS} \mathrm{KS}(+)$ with HindIII and $\mathrm{XbaI}$ and inserted into HindIII and XbaI-linearized expression vector $\mathrm{pBK}-\mathrm{CMV}$ (Agilent Technologies), resulting in pBK-CMV-p100. The cDNA encoding the chicken NF$\kappa \mathrm{B}$ p105 [141] cloned in pGEM4 was released by digestion with EcoRI and KpnI and inserted into EcoRI- and KpnI-linearized pBK-CMV, producing pBK-CMV-p105. The ankyrin repeats were removed from the 5 ' end of the NF-kB p105 cDNA by digestion with SacI. The chicken NF-kB p65 cDNA cloned in pTZ18R was released by digestion with $X h o I$ and $M f e I$ and re-cloned into XhoI and SmaI-linearized pBK-CMV producing pBK-CMV-p65. Plasmids were purified using the affinity chromatography columns (Qiagen) and proper structure of all the plasmids was verified by restriction enzymes digest and sequencing.

\section{Promoter assays}

The activity of CD30 and Meq promoters was analyzed in vitro by promoter reporter assays. First, the reporter gene d2EGFP was placed under the control of the CD30 and Meq promoters and the coding sequences of transcription factors (Meq oncogene, and NF-kB p65, p100 and p105) were cloned into the expression plasmid $\mathrm{pBK}-$ CMV (see Construction of plasmids above). The 
promoter reporter plasmids and transcription factor expression plasmids were then transfected into SOgE cells [101], and the expression of the reporter gene was quantitatively measured by duplex real-time PCR as described below.

SOgE cells were grown in Dulbecco's modified Eagle's minimum essential medium supplemented with $10 \%$ fetal calf serum, penicillin (100 IU/mL), streptomycin $(100 \mathrm{mg} / \mathrm{mL})$ and amphotericin B $(0.25 \mu \mathrm{g} / \mathrm{mL})$ at $37^{\circ} \mathrm{C}$ with $5 \% \mathrm{CO}_{2}$. Plasmids were transfected in triplicate into SOgE cells in 24 well plates at $80 \%$ confluence using Lipofectin ${ }^{\circledR}$ reagent (Life Technologies) following the manufacturer's instructions. Each well was transfected with 200-400 ng of DNA. To determine the effect of the Meq oncogene on the activity of the chicken CD30 promoters SOgE cells were transfected with either pUC18 alone (200 ng/well, negative control), pd2EGFP-N1 alone (200 ng/well, positive control), pd2EGFP-CD30 alone (200 ng/well, to measure the baseline level of expression from each of the CD30 promoters), or with a mix of pBK-CMV-Meq and pd2EGFP-CD30 (200 ng of each plasmid/well). To determine the transactivation effect of the NF- $\mathrm{kB}$ transcription factors alone or in combination with the Meq oncoprotein on the Meq promoter SOgE cells were transfected with plasmid mixtures and DNA. Plasmid pUC18 was added to transfection mixtures to give total amount of $400 \mathrm{ng}$ plasmid DNA per well whenever it was necessary. Total RNA was isolated from transfected SOgE cells $48 \mathrm{~h}$ post transfection using TRI reagent (Molecular Research Center) following the manufacturer's instructions. Isolated RNA was treated with DNaseI, extracted with phenol/chloroform, precipitated with ethanol and resuspended in water.

The d2EGFP mRNA levels in transfected SOgE cells were quantified using the Platinum Quantitative RTPCR ThermoScript One-Step System (Life Technologies). Both, d2EGFP and 28S rRNA amplicons, were designed using Beacon Designer (PREMIER Biosoft). The reaction mixture consisted of $2 \mathrm{X}$ ThermoScript Reaction buffer, $10 \mu \mathrm{M}$ of each primer, $1 \mu \mathrm{M}$ each of probes, Platinum Taq DNA polymerase and $1 \mu \mathrm{L}$ of total RNA (5 ng/ $/ \mathrm{L}$ ) and the total volume was made to $12.5 \mu \mathrm{L}$ with RNAase free water as filler. Amplification and detection was done on iCycler iQ Real-Time PCR Detection System (Bio-Rad) with the cycle profile of $50^{\circ} \mathrm{C}$ for $30 \mathrm{~min}$ and $95^{\circ} \mathrm{C}$ for $5 \mathrm{~min}$, followed by 45 cycles of $95^{\circ} \mathrm{C}$ for $15 \mathrm{~s}$ and $60^{\circ} \mathrm{C}$ for $1 \mathrm{~min}$. Each QPCR experiment included, samples (in triplicate), two no-template controls and a dilution series $(5,10,50$, 100,500 and 1000) of total RNA made by mixing a 10 $\mu \mathrm{L}$ aliquot from all samples). Standard curves for d2EGFP and 28S rRNA were generated from the dilution series and the ratio of coefficient of regression values (for 28S RNA and d2EGFP) was used to calculate correction factor for PCR efficiency between these two genes. Both d2EGFP and 28S rRNA cycle threshold $(\mathrm{Ct})$ values were subsequently normalized for correction factor for PCR efficiency. Mean Ct value for 28S rRNA was used to normalize the d2EGFP Ct values for any volume error. The means of the normalized $\mathrm{Ct}$ values were used to compare the relative percent expression compared to d2EGFP expression driven by the CMV promoter by doing one way ANOVA.

\section{Gene ontology (GO) based phenotype modeling}

GO was used to identify the phenotype of $\mathrm{CD} 30^{\text {hi }}$ and $\mathrm{CD} 30^{\text {lo }}$ cells, specifically with respect to GO terms which are associated with cancer [3]. The GO annotations were obtained using tools available at AgBase [142] and modeled as described previously in [3]. Briefly, all the annotations those were either agonistic or antagonistic to specific biological processes which included activation, angiogenesis, apoptosis, cell cycle, differentiation, DNA damage response, migration, oxidative stress, and proliferation and telomere maintenance [3], were selected and the difference between the number of agonistic and antagonistic annotations indicated the overall phenotype for that particular GO term. GO-modeler based modeling for T-regulatory cells was done as described in $[6,12]$ for both transcriptomics and proteomics data.

\section{mRNA and protein expression comparison}

We calculated the fold change in amount of mRNAs and proteins transcripts in $\mathrm{CD} 30^{\mathrm{hi}}$ cells compared to $\mathrm{CD}^{10}{ }^{\text {lo }}$ cells in semi-quantitative manner. For microarray data we calculated the fold change in terms of ratio of normalized fluorescent intensities; for proteomics data, fold change was calculated by taking the ratio of mean sum of XCorr of that protein in CD30 ${ }^{\text {hi }}$ to CD $30^{\text {lo }}$ cells.

\section{Additional files}

Additional file 1: Additional file 1 contains four worksheets, sheet 1
$\left(C D 30^{\text {hi }}\right.$ Vs. CD $30^{\text {lo }}$ protein expression): contains proteins identified
from $C D 30^{\text {lo }}$ and $C D 30^{\text {hi }}$ cells, worksheet 2 (ChIP identified
proteins): contains proteins identified in ChIP experiment. Worksheet
3 (NF $K B$ isoforms subcellular locations): contains actual numbers of
peptides of different isoforms of NF-KB in nuclear and extranuclear
fractions, and worksheet 4 (Phosphorylated peptides locations) contains
actual numbers of phosphorylated and non-phosphorylated peptides
identified.
Additional file 2: Additional file 2 contains three worksheets, sheet
$\mathbf{1}$ contains the results from the statistical analysis of microarray
data, sheet 2 contains expression data for only miRNAs and sheet 3
contains predicted targets genes and the relative protein
expression of the targets of the miRNAs.

Additional file 1: Additional file 1 contains four worksheets, sheet 1 from $\mathrm{CD}_{30} 0^{\text {lo }}$ and $\mathrm{CD} 30^{\text {hi }}$ cells, worksheet 2 (ChIP identified proteins): contains proteins identified in ChIP experiment. Worksheet 3 (NF KB isoforms subcellular locations): contains actual numbers of peptides of different isoforms of NF-KB in nuclear and extranuclear fractions, and worksheet 4 (Phosphorylated peptides locations) contains actual numbers of phosphorylated and non-phosphorylated peptides

Additional file 2: Additional file 2 contains three worksheets, sheet 1 contains the results from the statistical analysis of microarray contains predicted targets genes and the relative protein expression of the targets of the miRNAs. 
Additional file 3: Additional file 3 contains mRNA and protein
expression fold changes in terms of $C D 30^{\text {hi }}$ over $C D 30^{\text {lo }}$ cells.

Additional file 4: Additional file 4 contains pentile wise Meq binding sites for 88 concordantly expressed host host gene products.

\section{Competing interests}

The authors declare that they have no competing interests.

\section{Authors' contributions}

JB did chicken infection experiment, RNA and protein isolation. SK and JB did protein isolation. SK did microarray, proteomics, and systems biology data analysis and wrote the manuscript. DK did plasmid construction, and transcription reporter assays and SNP assays. HI did the microarray experiments and data analysis. KP did the proteomics 2D LC ESI MS/MS experiment and data analysis. SS did ChIP assay. SB conceived the project, did data analysis and wrote the manuscript. $\mathrm{HC}$ and $\mathrm{HZ}$ provided the necessary support for microarray, western blot and ChIP experiments and reviewed the manuscript. All authors read and approved the final manuscript.

\section{Acknowledgement}

This paper was supported by USDA NRI 2006-35204-16549.

\section{Author details}

'Department of Pathobiology and Population Medicine, Mississippi State University, PO Box 6100, MS, Mississippi State 39762, USA. ${ }^{2}$ Institut für Virologie, Freie Universität Berlin, Berlin, Germany. ${ }^{3}$ School of Life Sciences and Bioengineering, Nelson Mandela African Institute of Science and Technology, PO Box 447, Arusha, Tanzania. ${ }^{4}$ Department of Bioengineering, University of California-San Diego, 9500 Gilman Dr, La Jolla, CA 92093, USA. ${ }^{5}$ Department of Poultry Science, College of Agriculture and Life Sciences, Texas A\&M University, College Station, TX 77843, USA. ${ }^{6}$ Comparative Medicine and Integrative Biology Graduate Program, College of Veterinary Medicine, Michigan State University, East Lansing, MI 48824, USA. ${ }^{7}$ College of Agriculture and Life Sciences, University of Arizona, P.O. Box 210036, Tucson, AZ 85721, USA. ${ }^{8}$ USDA-ARS, Avian Disease and Oncology Laboratory, 4279 East Mount Hope Road, East Lansing, MI 48823, USA.

Received: 13 June 2012 Accepted: 4 September 2012

Published: 14 September 2012

\section{References}

1. Felberbaum RS: The molecular mechanisms of classic Hodgkin's lymphoma. Yale J Biol Med 2005, 78:203-210.

2. Jemal A, Siegel R, Ward E, Murray T, Xu J, Thun MJ: Cancer statistics, 2007. CA Cancer J Clin 2007, 57:43-66

3. Buza JJ, Burgess SC: Modeling the proteome of a Marek's disease transformed cell line: a natural animal model for CD30 overexpressing lymphomas. Proteomics 2007, 7:1316-1326.

4. Willemze R, Beljaards RC: Spectrum of primary cutaneous CD30 (Ki-1)positive lymphoproliferative disorders. A proposal for classification and guidelines for management and treatment. J Am Acad Dermatol 1993, 28:973-980.

5. Willemze R, Kerl H, Sterry W, Berti E, Cerroni L, Chimenti S, Diaz-Perez JL, Geerts ML, Goos M, Knobler R, et al: EORTC classification for primary cutaneous lymphomas: a proposal from the Cutaneous Lymphoma Study Group of the European Organization for Research and Treatment of Cancer. Blood 1997, 90:354-371.

6. Kumar S: Buza JJ. Burgess SC: Genotype-Dependent Tumor Regression in Marek's Disease Mediated at the Level of Tumor Immunity. Cancer Microenviron; 2009.

7. Burgess SC: Marek's Disease Lymphomas. In Marek's Disease An Evolving Problem. Edited by Davison F, Nair V. Oxford: Elsevier Academic Press; 2004:109. Pastoret P-P (Series Editor).

8. Aldinucci D, Gloghini A, Pinto A, De Filippi R, Carbone A: The classical Hodgkin's lymphoma microenvironment and its role in promoting tumour growth and immune escape. J Pathol 2010, 221:248-263. http://www.ncbi.nlm.nih.gov/pubmed/20527019?dopt=Citation.
9. Burgess SC, Basaran BH, Davison TF: Resistance to Marek's disease herpesvirus-induced lymphoma is multiphasic and dependent on host genotype. Vet Pathol 2001, 38:129-142.

10. Abdulamir AS, Kadhim HS, Hafidh RR, Ali MA, Faik I, Abubakar F, Abbas KA: Severity of asthma: the role of CD25+, CD30+, NF-kappaB, and apoptotic markers. J Investig Allergol Clin Immunol 2009, 19:218-224.

11. Xie P, Kraus ZJ, Stunz LL, Bishop GA: Roles of TRAF molecules in B lymphocyte function. Cytokine Growth Factor Rev 2008, 19:199-207.

12. Shack LA, Buza JJ, Burgess SC: The neoplastically transformed (CD30(hi)) Marek's disease lymphoma cell phenotype most closely resembles T-;regulatory cells. Cancer Immunol Immunother 2008, 57:1253-1262.

13. Gascoyne RD, Rosenwald A, Poppema S, Lenz G: Prognostic biomarkers in malignant lymphomas. Leuk Lymphoma 2010, 51(Suppl 1):11-19. http:// www.ncbi.nlm.nih.gov/pubmed/20658955?dopt=Citation.

14. Herreros B, Sanchez-Aguilera A, Piris MA: Lymphoma microenvironment: culprit or innocent? Leukemia 2008, 22:49-58.

15. Burgess SC, Davison TF: Identification of the neoplastically transformed cells in Marek's disease herpesvirus-induced lymphomas: recognition by the monoclonal antibody AV37. J Virol 2002, 76:7276-7292.

16. Ghosh S, May MJ, Kopp EB: NF-kappa B and Rel proteins: evolutionarily conserved mediators of immune responses. Annu Rev Immunol 1998, 16:225-260.

17. Horie $R$, Watanabe $T$, Morishita $Y$, Ito K, Ishida T, Kanegae $Y$, Saito I, Higashihara M, Mori S, Kadin ME: Ligand-independent signaling by overexpressed CD30 drives NF-kappaB activation in Hodgkin-ReedSternberg cells. Oncogene 2002, 21:2493-2503.

18. Burgess SC, Young JR, Baaten BJ, Hunt L, Ross LN, Parcells MS, Kumar PM, Tregaskes CA, Lee LF, Davison TF: Marek's disease is a natural model for lymphomas overexpressing Hodgkin's disease antigen (CD30). Proc Natl Acad Sci USA 2004, 101:13879-13884.

19. Ross N, O'Sullivan G, Rothwell C, Smith G, Burgess SC, Rennie M, Lee LF, Davison TF: Marek's disease virus EcoRI-Q gene (meq) and a small RNA antisense to ICP4 are abundantly expressed in CD4+ cells and cells carrying a novel lymphoid marker, AV37, in Marek's disease lymphomas. $J$ Gen Virol 1997, 78(Pt 9):2191-2198.

20. Liu JL, Kung HJ: Marek's disease herpesvirus transforming protein MEQ: a c-Jun analogue with an alternative life style. Virus Genes 2000, 21:51-64.

21. Brown AC, Smith LP, Kgosana L, Baigent SJ, Nair V, Allday MJ: Homodimerization of the Meq viral oncoprotein is necessary for induction of T-cell lymphoma by Marek's disease virus. J Virol 2009, 83:11142-11151.

22. Chen G, Gharib TG, Huang CC, Taylor JM, Misek DE, Kardia SL, Giordano TJ, lannettoni MD, Orringer MB, Hanash SM, Beer DG: Discordant protein and mRNA expression in lung adenocarcinomas. Mol Cell Proteomics 2002, 1:304-313.

23. Gygi SP, Rochon Y, Franza BR, Aebersold R: Correlation between protein and mRNA abundance in yeast. Mol Cell Biol 1999, 19:1720-1730.

24. Hornshoj H, Bendixen E, Conley LN, Andersen PK, Hedegaard J, Panitz F, Bendixen C: Transcriptomic and proteomic profiling of two porcine tissues using high-throughput technologies. BMC Genomics 2009, 10:30.

25. Kanehisa M, Goto S, Furumichi M, Tanabe M, Hirakawa M: KEGG for representation and analysis of molecular networks involving diseases and drugs. Nucleic Acids Res 2010, 38:D355-D360. http://www.ncbi.nlm.nih gov/pubmed/19880382?dopt=Citation.

26. Buza JJ, Burgess SC: Different Signaling Pathways Expressed by Chicken Naive CD4(+) T Cells, CD4(+) Lymphocytes Activated with Staphylococcal Enterotoxin B, and Those Malignantly Transformed by Marek's Disease Virus. J Proteome Res 2008, 7(6):2380-2387. Epub 2008 Apr 16 http://www.ncbi.n/m.nih.gov/pubmed/18412384.

27. Terry KL, Tworoger SS, Gates MA, Cramer DW, Hankinson SE: Common Genetic Variation in IGF1, IGFBP1, and IGFBP3 and Ovarian Cancer Risk. Carcinogenesis 2009, 30(12):2042-2046. http://www.ncbi.nlm.nih.gov/ pubmed/19858071?dopt=Citation.

28. Eleswarapu S, Ge X, Wang Y, Yu J, Jiang H: Growth hormone-activated STAT5 may indirectly stimulate IGF-I gene transcription through HNF-3 \{gamma\}. Mol Endocrinol 2009, 23:2026-2037.

29. Liu HC, Kung HJ, Fulton JE, Morgan RW, Cheng HH: Growth hormone interacts with the Marek's disease virus SORF2 protein and is associated with disease resistance in chicken. Proc Natl Acad Sci USA 2001, 98:9203-9208. 
30. Choi YL, Tsukasaki K, O'Neill MC, Yamada Y, Onimaru Y, Matsumoto K, Ohashi J, Yamashita Y, Tsutsumi S, Kaneda R, et al: A genomic analysis of adult T-cell leukemia. Oncogene 2007, 26:1245-1255.

31. Onimaru Y, Tsukasaki K, Murata K, Imaizumi $Y$, Choi $Y L$, Hasegawa $H$, Sugahara K, Yamada Y, Hayashi T, Nakashima M, et al: Autocrine and/or paracrine growth of aggressive ATLL cells caused by HGF and c-Met. Int J Oncol 2008, 33:697-703.

32. Montaldo F, Maffe A, Morini M, Noonan D, Giordano S, Albini A, Prat M: Expression of functional tyrosine kinases on immortalized Kaposi's sarcoma cells. J Cell Physiol 2000, 184:246-254.

33. Jucker M, Gunther A, Gradl G, Fonatsch C, Krueger G, Diehl V, Tesch H: The Met/hepatocyte growth factor receptor (HGFR) gene is overexpressed in some cases of human leukemia and lymphoma. Leuk Res 1994, 18:7-16.

34. Wang X, DeFrances MC, Dai Y, Pediaditakis P, Johnson C, Bell A, Michalopoulos GK, Zarnegar R: A mechanism of cell survival: sequestration of Fas by the HGF receptor Met. Mol Cell 2002, 9:411-421.

35. Karabatsou K, Pal P, Dodd S, Mat A, Haylock B, Aguirreburualde M, Moxam $\mathrm{N}$, Pinson-Ellis W, Broome J, Rainov NG: Expression of survivin, plateletderived growth factor A (PDGF-A) and PDGF receptor alpha in primary central nervous system lymphoma. J Neurooncol 2006, 79:171-179.

36. Chen YP, Chang KC, Su WC, Chen TY: The expression and prognostic significance of platelet-derived growth factor receptor alpha in mature T- and natural killer-cell lymphomas. Ann Hematol 2008, 87:985-990.

37. Brown RE, Nazmi RK: The Reed-Steinberg cell: molecular characterization by proteomic analysis with therapeutic implications. Ann Clin Lab Sci 2002, 32:339-351.

38. Wang SC, Hung MC: Nuclear Translocation of the Epidermal Growth Factor Receptor Family Membrane Tyrosine Kinase Receptors. Clinical Cancer Res 2009, 15(21):6484-6489. Epub 2009 Oct 27. http://www.ncbi.nlm. nih.gov/pubmed/19861462?dopt=Citation.

39. Levy AM, Gilad O, Xia L, Izumiya Y, Choi J, Tsalenko A, Yakhini Z, Witter R, Lee L, Cardona CJ, Kung HJ: Marek's disease virus Meq transforms chicken cells via the v-Jun transcriptional cascade: a converging transforming pathway for avian oncoviruses. Proc Natl Acad Sci USA 2005, 102:14831-14836.

40. McCubrey JA, Steelman LS, Abrams SL, Lee JT, Chang F, Bertrand FE, Navolanic PM, Terrian DM, Franklin RA, D'Assoro AB, et al: Roles of the RAF/ MEK/ERK and PI3K/PTEN/AKT pathways in malignant transformation and drug resistance. Adv Enzyme Regul 2006, 46:249-279.

41. Zhang S, Yu D: PI(3)king apart PTEN's role in cancer. Clinical cancer research: an official journal of the American Association for Cancer Research 2010, 16:4325-4330.

42. Hanahan D, Weinberg RA: The hallmarks of cancer. Cell 2000, 100:57-70.

43. Weinberg RA: The retinoblastoma protein and cell cycle control. Cell 1995, 81:323-330.

44. Polakis P: Wnt signaling and cancer. Genes Dev 2000, 14:1837-1851.

45. Groen RW, Oud ME, Schilder-Tol EJ, Overdijk MB, ten Berge D, Nusse R, Spaargaren M, Pals ST: Illegitimate WNT pathway activation by betacatenin mutation or autocrine stimulation in T-cell malignancies. Cancer Res 2008, 68:6969-6977.

46. Liu JL, Ye Y, Lee LF, Kung HJ: Transforming potential of the herpesvirus oncoprotein MEQ: morphological transformation, serum-independent growth, and inhibition of apoptosis. J Virol 1998, 72:388-395.

47. Didelot C, Schmitt E, Brunet M, Maingret L, Parcellier A, Garrido C: Heat shock proteins: endogenous modulators of apoptotic cell death. Handb Exp Pharmacol 2006, (172):171-198. http://www.ncbi.n/m.nih.gov/pubmed/ 16610360?dopt=Citation)

48. Dudeja V, Mujumdar N, Phillips P, Chugh R, Borja-Cacho D, Dawra RK, Vickers SM, Saluja AK: Heat shock protein 70 inhibits apoptosis in cancer cells through simultaneous and independent mechanisms. Gastroenterology 2009, 136:1772-1782.

49. Zhao Y, Kurian D, Xu H, Petherbridge L, Smith LP, Hunt L, Nair V: Interaction of Marek's disease virus oncoprotein Meq with heat-shock protein 70 in lymphoid tumour cells. J Gen Virol 2009, 90:2201-2208.

50. Glaessgen A, Jonmarker S, Lindberg A, Nilsson B, Lewensohn R, Ekman P, Valdman A, Egevad L: Heat shock proteins 27, 60 and 70 as prognostic markers of prostate cancer. APMIS 2008, 116:888-895.

51. McTavish N, Copeland LA, Saville MK, Perkins ND, Spruce BA: Proenkephalin assists stress-activated apoptosis through transcriptional repression of NF-kappaB- and p53-regulated gene targets. Cell Death Differ 2007, $14: 1700-1710$
52. Belgiovine C, Chiodi I, Mondello C: Telomerase: cellular immortalization and neoplastic transformation. Multiple functions of a multifaceted complex. Cytogenet Genome Res 2008, 122:255-262.

53. Baumann $P$, Cech TR: Pot 1 , the putative telomere end-binding protein in fission yeast and humans. Science 2001, 292:1171-1175.

54. Pitt CW, Cooper JP: Pot1 inactivation leads to rampant telomere resection and loss in one cell cycle. Nucleic Acids Res 2010, 38(20):6968-6975. Epub 2010 Jul 3.( http://www.ncbi.nlm.nih.gov/pubmed/20601686?dopt=Citation).

55. Shen R, Ye Y, Chen L, Yan Q, Barsky SH, Gao JX: Precancerous stem cells can serve as tumor vasculogenic progenitors. PLoS One 2008, 3:e1652.

56. Khanna C, Wan X, Bose S, Cassaday R, Olomu O, Mendoza A, Yeung C, Gorlick R, Hewitt SM, Helman LJ: The membrane-cytoskeleton linker ezrin is necessary for osteosarcoma metastasis. Nat Med 2004, 10:182-186.

57. Bruce B, Khanna G, Ren L, Landberg G, Jirstrom K, Powell C, Borczuk A, Keller ET, Wojno KJ, Meltzer P, et al: Expression of the cytoskeleton linker protein ezrin in human cancers. Clin Exp Metastasis 2007, 24:69-78.

58. Bretscher A, Edwards K, Fehon RG: ERM proteins and merlin: integrators at the cell cortex. Nat Rev Mol Cell Biol 2002, 3:586-599.

59. Martin TA, Harrison G, Mansel RE, Jiang WG: The role of the CD44/ezrin complex in cancer metastasis. Crit Rev Oncol Hematol 2003, 46:165-186.

60. Kang YK, Hong SW, Lee H, Kim WH: Prognostic implications of ezrin expression in human hepatocellular carcinoma. Mol Carcinog 2010, 49:798-804.

61. Ma PC, Maulik G, Christensen J: Salgia R: c-Met: structure, functions and potential for therapeutic inhibition. Cancer Metastasis Rev 2003, 22:309-325.

62. Long ET, Baker S, Oliveira V, Sawitzki B, Wood KJ: Alpha-1,2-mannosidase and hence $\mathrm{N}$-glycosylation are required for regulatory $\mathrm{T}$ cell migration and allograft tolerance in mice. PLoS One 2010, 5:e8894. http://www.ncbi. nlm.nih.gov/pubmed/20126660?dopt=Citation.

63. Basler T, Jeckstadt S, Valentin-Weigand P, Goethe R: Mycobacterium paratuberculosis, Mycobacterium smegmatis, and lipopolysaccharide induce different transcriptional and post-transcriptional regulation of the IRG1 gene in murine macrophages. J Leukoc Biol 2006, 79:628-638.

64. Smith J, Sadeyen JR, Paton IR, Hocking PM, Salmon N, Fife M, Nair V, Burt DW, Kaiser P: Systems analysis of immune responses in Marek's disease virus-infected chickens identifies a gene involved in susceptibility and highlights a possible novel pathogenicity mechanism. J Virol 2011, 85:11146-11158.

65. Yu Y, Zhang $H$, Tian F, Zhang W, Fang H, Song J: An integrated epigenetic and genetic analysis of DNA methyltransferase genes (DNMTs) in tumor resistant and susceptible chicken lines. PLOS One 2008, 3:e2672.

66. Burgess SC, Davison TF: A quantitative duplex PCR technique for measuring amounts of cell-associated Marek's disease virus: differences in two populations of lymphoma cells. J Virol Methods 1999, 82:27-37.

67. Young LS, Murray PG: Epstein-Barr virus and oncogenesis: from latent genes to tumours. Oncogene 2003, 22:5108-5121.

68. Minarovits J: Epigenotypes of latent herpesvirus genomes. Curr Top Microbiol Immunol 2006, 310:61-80.

69. McCarthy FM, Mahony TJ, Parcells MS, Burgess SC: Understanding animal viruses using the Gene Ontology. Trends Microbiol 2009, 17:328-335.

70. Parvizi $P$, Andrzejewski $K$, Read LR, Behboudi S, Sharif S: Expression profiling of genes associated with regulatory functions of T-cell subsets in Marek's disease virus-infected chickens. Avian pathology: journal of the WVPA 2010, 39:367-373.

71. Chiang HI, Swaggerty $C L$, Kogut MH, Dowd SE, Li X, Pevzner IY, Zhou H: Gene expression profiling in chicken heterophils with Salmonella enteritidis stimulation using a chicken $44 \mathrm{~K}$ Agilent microarray. BMC Genomics 2008, 9:526.

72. Li X, Chiang HI, Zhu J, Dowd SE, Zhou H: Characterization of a newly developed chicken 44 K Agilent microarray. BMC Genomics 2008, 9:60.

73. Friedenson B: The BRCA1/2 pathway prevents hematologic cancers in addition to breast and ovarian cancers. BMC Cancer 2007, 7:152.

74. Zhou M, Fadlelmola FM, Cohn JB, Skinnider B, Gascoyne RD, Banerjee D: Constitutive overexpression of a novel 21 kDa protein by Hodgkin lymphoma and aggressive non-Hodgkin lymphomas. Mol Cancer 2008 7:12.

75. Voorzanger-Rousselot N, Alberti L, Blay JY: CD40L induces multidrug resistance to apoptosis in breast carcinoma and lymphoma cells through caspase independent and dependent pathways. BMC Cancer 2006, 6:75. 
76. Ma $Y$, Visser $L$, Roelofsen $H$, de Vries $M$, Diepstra A, van Imhoff $G$, van der Wal T, Luinge M, Alvarez-Llamas G, Vos H, et al: Proteomics analysis of Hodgkin lymphoma: identification of new players involved in the crosstalk between HRS cells and infiltrating lymphocytes. Blood 2008, 111:2339-2346.

77. Mulaomerovic A, Halilbasic A, Cickusic E, Zavasnik-Bergant T, Begic L, Kos J: Cystatin $C$ as a potential marker for relapse in patients with non-Hodgkin B-cell lymphoma. Cancer Lett 2007, 248:192-197.

78. Poteryaeva ON, Falameyeva OV, Korolenko TA, Kaledin VI, Djanayeva SJ, Nowicky JW, Sandula J: Cysteine proteinase inhibitor level in tumor and normal tissues in control and cured mice. Drugs Exp Clin Res 2000, 26:301-306.

79. Poteryaeva ON, Falameeva OV, Zhanaeva SY, Svechnikova IG, Korolenko TA Kaledin Vl: Role of cystatin C and cysteine proteinases in the development of mouse LS-lymphosarcoma. Bull Exp Biol Med 2001, 132:675-677.

80. Horie R, Higashihara M, Watanabe T: Hodgkin's lymphoma and CD30 signal transduction. Int J Hematol 2003, 77:37-47.

81. Shi GP, Sukhova GK, Grubb A, Ducharme A, Rhode LH, Lee RT, Ridker PM, Libby $P$, Chapman HA: Cystatin C deficiency in human atherosclerosis and aortic aneurysms. J Clin Invest 1999, 104:1191-1197.

82. Kos J, Stabuc B, Schweiger A, Krasovec M, Cimerman N, Kopitar-Jerala N, Vrhovec I: Cathepsins $B, H$, and $L$ and their inhibitors stefin $A$ and cystatin $C$ in sera of melanoma patients. Clinical cancer research: an official journal of the American Association for Cancer Research 1997, 3:1815-1822.

83. Joyce JA, Baruch A, Chehade K, Meyer-Morse N, Giraudo E, Tsai FY, Greenbaum DC, Hager JH, Bogyo M, Hanahan D: Cathepsin cysteine proteases are effectors of invasive growth and angiogenesis during multistage tumorigenesis. Cancer Cell 2004, 5:443-453.

84. Wang B, Sun J, Kitamoto S, Yang M, Grubb A, Chapman HA, Kalluri R, Shi GP: Cathepsin S controls angiogenesis and tumor growth via matrixderived angiogenic factors. J Biol Chem 2006, 281:6020-6029.

85. Qian Z, Brunovskis P, Rauscher F 3rd: Lee L, Kung HJ: Transactivation activity of Meq, a Marek's disease herpesvirus bZIP protein persistently expressed in latently infected transformed T cells. J Virol 1995 69:4037-4044

86. Carlson JM, Chakravarty A, DeZiel CE, Gross RH: SCOPE: a web server for practical de novo motif discovery. Nucleic Acids Res 2007, 35:W259-W264.

87. Burnside J, Ouyang M, Anderson A, Bernberg E, Lu C, Meyers BC, Green PJ, Markis M, Isaacs G, Huang E, Morgan RW: Deep sequencing of chicken microRNAs. BMC Genomics 2008, 9:185.

88. Lambeth LS, Yao Y, Smith LP, Zhao Y, Nair V: MicroRNAs 221 and 222 target p27Kip1 in Marek's disease virus-transformed tumour cell line MSB-1. J Gen Virol 2009, 90:1164-1171.

89. Yao $Y$, Zhao $Y$, Smith LP, Lawrie $C H$, Saunders NJ, Watson M, Nair V: Differential expression of microRNAs in Marek's disease virus transformed T-lymphoma cell lines. J Gen Virol 2009, 90:1551-1559.

90. Xu H, Yao Y, Smith LP, Nair V: MicroRNA-26a-mediated regulation of interleukin-2 expression in transformed avian lymphocyte lines. Cancer Cell Int 2010, 10:15. http://www.ncbi.nlm.nih.gov/pubmed/20441582? dopt=Citation

91. Wang $X$ : miRDB: a microRNA target prediction and functional annotation database with a wiki interface. RNA 2008, 14:1012-1017.

92. Wang X: El Naqa IM: Prediction of both conserved and nonconserved microRNA targets in animals. Bioinformatics 2008, 24:325-332.

93. Hoffmann A, Baltimore D: Circuitry of nuclear factor kappaB signaling. Immunol Rev 2006, 210:171-186.

94. Demchenko YN, Glebov OK, Zingone A, Keats JJ, Bergsagel PL, Kuehl WM: Classical and/or alternative NF\{kappa\}B pathway activation in multiple myeloma. Blood 2010, 115(17):3541-3552. Epub 2010 Jan 6. http://www. ncbi.nlm.nih.gov/pubmed/20053756?dopt=Citation

95. Kato M, Sanada M, Kato I, Sato Y, Takita J, Takeuchi K, Niwa A, Chen Y, Nakazaki K, Nomoto J, et al: Frequent inactivation of A20 in B-cell lymphomas. Nature 2009, 459:712-716.

96. Zandi E, Rothwarf DM, Delhase M, Hayakawa M, Karin M: The IkappaB kinase complex (IKK) contains two kinase subunits, IKKalpha and IKKbeta, necessary for IkappaB phosphorylation and NF-kappaB activation. Cell 1997, 91:243-252.

97. Wu C, Ghosh S: Differential phosphorylation of the signal-responsive domain of I kappa B alpha and I kappa B beta by I kappa B kinases. J Biol Chem 2003, 278:31980-31987.
98. Lin R, Beauparlant P, Makris C, Meloche S, Hiscott J: Phosphorylation of IkappaBalpha in the C-terminal PEST domain by casein kinase II affects intrinsic protein stability. Mol Cell Biol 1996, 16:1401-1409.

99. McElhinny JA, Trushin SA, Bren GD, Chester N, Paya CV: Casein kinase II phosphorylates I kappa B alpha at S-283, S-289, S-293, and T-291 and is required for its degradation. Mol Cell Biol 1996, 16:899-906.

100. Schwarz EM, Van Antwerp D, Verma IM: Constitutive phosphorylation of IkappaBalpha by casein kinase II occurs preferentially at serine 293: requirement for degradation of free IkappaBalpha. Mol Cell Biol 1996, 16:3554-3559.

101. Schumacher D, Tischer BK, Teifke JP, Wink K, Osterrieder N: Generation of a permanent cell line that supports efficient growth of Marek's disease virus (MDV) by constitutive expression of MDV glycoprotein E. J Gen Virol 2002, 83:1987-1992.

102. Stone HA: Use of highly inbred chickens in research.: USDA Agricultural Research Service Technical Bulletin No - 1514; 1975:1-21.

103. Bacon LD, Hunt HD, Cheng HH: A review of the development of chicken lines to resolve genes determining resistance to diseases. Poult Sci 2000 79:1082-1093.

104. Dennis R, Zhang HM, Cheng HW: Effect of selection for resistance and susceptibility to viral diseases on concentrations of dopamine and immunological parameters in six-week-old chickens. Poult Sci 2006, 85:2135-2140.

105. Tsunoda T, Takagi T: Estimating transcription factor bindability on DNA. Bioinformatics 1999, 15:622-630

106. Mantovani A: Molecular pathways linking inflammation and cancer. Curr Mol Med 2010, 10:369-373. http://www.ncbi.nlm.nih.gov/pubmed/ 20455855?dopt=Citation

107. Rayet B, Gelinas C: Aberrant rel/nfkb genes and activity in human cancer. Oncogene 1999, 18:6938-6947.

108. Lei X, Bai Z, Ye F, Xie J, Kim CG, Huang Y, Gao SJ: Regulation of NF-kappaB inhibitor IkappaBalpha and viral replication by a KSHV microRNA. Nat Cell Biol, 12:193-199. http://www.ncbi.nlm.nih.gov/pubmed/20081837? dopt=Citation

109. Sadagopan S, Sharma-Walia N, Veettil MV, Raghu H, Sivakumar R, Bottero V Chandran B: Kaposi's sarcoma-associated herpesvirus induces sustained NF-kappaB activation during de novo infection of primary human dermal microvascular endothelial cells that is essential for viral gene expression. J Virol 2007, 81:3949-3968.

110. Martin D, Galisteo R, Ji Y, Montaner S, Gutkind JS: An NF-kappaB gene expression signature contributes to Kaposi's sarcoma virus vGPCRinduced direct and paracrine neoplasia. Oncogene 2008, 27:1844-1852.

111. Keller SA, Hernandez-Hopkins D, Vider J, Ponomarev V, Hyjek E, Schattner EJ, Cesarman E: NF-kappaB is essential for the progression of KSHV- and EBV-infected lymphomas in vivo. Blood 2006, 107:3295-3302.

112. Carbone A, Gloghini A, Dotti G: EBV-associated lymphoproliferative disorders: classification and treatment. Oncologist 2008, 13:577-585.

113. Ling L, Cao Z, Goeddel DV: NF-kappaB-inducing kinase activates IKK-alpha by phosphorylation of Ser-176. Proc Natl Acad Sci USA 1998, 95:3792-3797.

114. Lawrence T, Bebien M, Liu GY, Nizet V, Karin M: IKKalpha limits macrophage NF-kappaB activation and contributes to the resolution of inflammation. Nature 2005, 434:1138-1143.

115. Bonizzi G, Karin M: The two NF-kappaB activation pathways and their role in innate and adaptive immunity. Trends Immunol 2004, 25:280-288.

116. Sun SC, Cesarman E: NF-kappaB as a Target for Oncogenic Viruses. Curr Top Microbiol Immunol 2010, 349:197-244. http://www.ncbi.nlm.nih.gov/ pubmed/20845110?dopt=Citation

117. Boehm D, Gewurz BE, Kieff E, Cahir-McFarland E: Epstein-Barr latent membrane protein 1 transformation site 2 activates NF-kappaB in the absence of NF-kappaB essential modifier residues 133-224 or 373-419. Proc Natl Acad Sci USA 2010, 107:18103-18108. http://www.ncbi.nlm.nih. gov/pubmed/20923877?dopt=Citation.

118. Murray RJ, Kurilla MG, Brooks JM, Thomas WA, Rowe M, Kieff E, Rickinson AB: Identification of target antigens for the human cytotoxic $T$ cell response to Epstein-Barr virus (EBV): implications for the immune control of EBVpositive malignancies. J Exp Med 1992, 176:157-168.

119. Omar AR, Schat KA: Syngeneic Marek's disease virus (MDV)-specific cellmediated immune responses against immediate early, late, and unique MDV proteins. Virology 1996, 222:87-99.

120. Khanna R, Burrows SR, Nicholls J, Poulsen LM: Identification of cytotoxic T cell epitopes within Epstein-Barr virus (EBV) oncogene latent membrane 
protein 1 (LMP1): evidence for HLA A2 supertype-restricted immune recognition of EBV-infected cells by LMP1-specific cytotoxic T lymphocytes. Eur J Immunol 1998, 28:451-458.

121. Lupiani B, Lee LF, Cui X, Gimeno I, Anderson A, Morgan RW, Silva RF, Witter RL, Kung HJ, Reddy SM: Marek's disease virus-encoded Meq gene is involved in transformation of lymphocytes but is dispensable for replication. Proc Natl Acad Sci USA 2004, 101:11815-11820.

122. Ajithdoss DK, Reddy SM, Suchodolski PF, Lee LF, Kung HJ, Lupiani B: In vitro characterization of the Meq proteins of Marek's disease virus vaccine strain CVI988. Virus Res 2009, 142:57-67.

123. Suchodolski PF, Izumiya Y, Lupiani B, Ajithdoss DK, Lee LF, Kung HJ, Reddy SM: Both homo and heterodimers of Marek's disease virus encoded Meq protein contribute to transformation of lymphocytes in chickens. Virology 2010, 399:312-321. http://www.ncbi.nlm.nih.gov/pubmed/20137800? dopt $=$ Citation

124. Deng X, Li X, Shen Y, Qiu Y, Shi Z, Shao D, Jin Y, Chen H, Ding C, Li L, et al: The Meq oncoprotein of Marek's disease virus interacts with p53 and inhibits its transcriptional and apoptotic activities. Virol J 2010, 7:348. http://www.ncbi.nlm.nih.gov/pubmed/21110861?dopt=Citation.

125. Franchina M, Kadin ME, Abraham L: Polymorphism of the CD30 promoter microsatellite repressive element is associated with development of primary cutaneous lymphoproliferative disorders. Cancer Epidemiol Biomarkers Prev 2005, 14:1322-1325.

126. Skinnider BF, Mak TW: The role of cytokines in classical Hodgkin lymphoma. Blood 2002, 99:4283-4297.

127. Matsuyama-Kato A, Murata S, Isezaki M, Kano R, Takasaki S, Ichii O, Konnai S, Ohashi K: Molecular characterization of immunoinhibitory factors PD-1/ PD-L1 in chickens infected with Marek's disease virus. Virol J 2012, 9:94.

128. Rachinel N, Salles G: The host-tumor interface in B-cell non-Hodgkin lymphoma: a new world to investigate. Curr Hematol Malig Rep 2009, 4:196-201.

129. Yang ZZ, Novak AJ, Ziesmer SC, Witzig TE, Ansell SM: CD70+ non-Hodgkin lymphoma $B$ cells induce Foxp3 expression and regulatory function in intratumoral CD4 + CD25 T cells. Blood 2007, 110:2537-2544.

130. Mittal S, Marshall NA, Duncan L, Culligan DJ, Barker RN, Vickers MA: Local and systemic induction of $\mathrm{CD} 4+\mathrm{CD} 25+$ regulatory T-cell population by non-Hodgkin lymphoma. Blood 2008, 111:5359-5370.

131. Maggio E, van den Berg A, Diepstra A, Kluiver J, Visser L, Poppema S: Chemokines, cytokines and their receptors in Hodgkin's lymphoma cell lines and tissues. Ann Oncol 2002, 13(Suppl 1):52-56.

132. Baumforth KR, Birgersdotter A, Reynolds GM, Wei W, Kapatai G, Flavell JR, Kalk E, Piper K, Lee S, Machado L, et al: Expression of the Epstein-Barr virus-encoded Epstein-Barr virus nuclear antigen 1 in Hodgkin's lymphoma cells mediates Up-regulation of CCL20 and the migration of regulatory T cells. Am J Pathol 2008, 173:195-204.

133. Engel AT, Selvaraj RK, Kamil JP, Osterrieder N, Kaufer BB: Marek's disease viral interleukin-8 (vlL-8) promotes lymphoma formation through targeted recruitment of B-cells and CD4+CD25+ T-cells. J Virol 2012, 86(16):8536-8545. Epub 2012 May 30.( http://www.ncbi.nlm.nih.gov/ pubmed/22647701.

134. Griffiths-Jones S: The microRNA Registry. Nucleic Acids Res 2004, 32:D109-D111.

135. Griffiths-Jones S, Grocock RJ, van Dongen S, Bateman A: Enright AJ: miRBase: microRNA sequences, targets and gene nomenclature. Nucleic Acids Res 2006, 34:D140-D144.

136. McCarthy FM, Burgess SC, van den Berg BH, Koter MD, Pharr GT: Differential detergent fractionation for non-electrophoretic eukaryote cell proteomics. J Proteome Res 2005, 4:316-324

137. Pendarvis K, Kumar R, Burgess SC, Nanduri B: An automated proteomic data analysis workflow for mass spectrometry. BMC Bioinformatics 2009, 10(Suppl 11):S17.

138. Beausoleil SA, Villen J, Gerber SA, Rush J, Gygi SP: A probability-based approach for high-throughput protein phosphorylation analysis and site localization. Nat Biotechnol 2006, 24:1285-1292.

139. Han G, Ye M, Jiang X, Chen R, Ren J, Xue Y, Wang F, Song C, Yao X, Zou H: Comprehensive and reliable phosphorylation site mapping of individual phosphoproteins by combination of multiple stage mass spectrometric analysis with a target-decoy database search. Anal Chem 2009, 81:5794-5805.
140. Sif S, Gilmore TD: NF-kappa B p100 is one of the high-molecular-weight proteins complexed with the $v$-Rel oncoprotein in transformed chicken spleen cells. J Virol 1993, 67:7612-7617.

141. Capobianco AJ, Chang D, Mosialos G, Gilmore TD: p105, the NF-kappa B p50 precursor protein, is one of the cellular proteins complexed with the v-Rel oncoprotein in transformed chicken spleen cells. J Virol 1992, 66:3758-3767.

142. McCarthy FM, Bridges SM, Wang N, Magee GB, Williams WP, Luthe DS, Burgess SC: AgBase: a unified resource for functional analysis in agriculture. Nucleic Acids Res 2007, 35:D599-D603.

doi:10.1186/1752-0509-6-123

Cite this article as: Kumar et al:: Nuclear Factor kappa B is central to Marek's Disease herpesvirus induced neoplastic transformation of CD30 expressing lymphocytes in-vivo. BMC Systems Biology 2012 6:123.

\section{Submit your next manuscript to BioMed Central and take full advantage of:}

- Convenient online submission

- Thorough peer review

- No space constraints or color figure charges

- Immediate publication on acceptance

- Inclusion in PubMed, CAS, Scopus and Google Scholar

- Research which is freely available for redistribution

Submit your manuscript at www.biomedcentral.com/submit

C Biomed Central 